\title{
Las láminas de las guerras Tenochcas en Tovar y Durán. Variantes y equívocos
}

por

Clementina Battcock ${ }^{1}$

Dirección de Estudios Históricos - INAH
Alejandra Dávila Montoya ${ }^{2}$

Posgrado en Estudios Mesoamericanos - UNAM

Existen dos versiones de la guerra entre Tenochtitlan y Azcapotzalco contenidas en tres fuentes de tradición indígena de la segunda mitad del siglo XVI: la Historia de las Indias de Nueva España e Islas de la Tierra Firme de Diego Durán, y las dos derivadas de la Segunda Relación de Juan de Tovar: el Códice Ramírez y el Manuscrito Tovar. Mediante el análisis de las diferencias entre los relatos alfabéticos y pictográficos del episodio que ofrecen tales textos, el presente artículo expone y discute las disparidades y confusiones existentes en los materiales pictográficos que acompañan estas obras.

Palabras Clave: guerra; Azcapotzalco; Tenochtitlan; láminas; Durán; Tovar.

Cómo CITAR ESTE ARTículo / CitaTion: Battcock, Clementina y Dávila Montoya, Alejandra, "Las láminas de las guerras tenochcas en Tovar y Durán. Variantes y equívocos", Revista de Indias, LXXVII/271 (Madrid, 2017): 691-725. doi:10.3989/revindias.2017.020

La derrota de Azcapotzalco - centro rector que extendió su influencia política y territorial en el valle de México entre los años de 1325 a 1430 a manos de los tenochcas, y la formación de una tercera Triple Alianza, constituida por Tetzcoco, Tenochtitlan y Tlacopan, marcó uno de los momentos políticos más significativos del período posclásico en el centro de México. En tiempos prehispánicos, esta famosa guerra fue consignada en los códices y en los relatos orales, pero también trascendió a las fuentes elaboradas durante el período colonial sobre el pasado indígena, como narraciones comprobatorias

1 cbattcock@yahoo.com.ar; ORCID: orcid.org/0000-0002-9899-1214.

2 alexia_2908@yahoo.com.mx; ORCID: orcid.org/0000-0002-4085-7362. 
para exigir el reconocimiento de antiguos derechos heredados. Así aparece en los Anales de Tlatelolco, los Anales de Culhuacán, el Códice Mexicanus, el Códice Azcatitlan, la Historia de las Indias de Nueva España e Islas de la Tierra Firme de Diego Durán, el Códice Ramírez y el Manuscrito Tovar de Phillips, la Crónica Mexicana y la Crónica Mexicayotl de Fernando Alvarado Tezozómoc, los Anales Mexicanos de México y Azcapotzalco, y la Relación Tercera y Séptima de Domingo Francisco de San Antón Chimalpahin Cuauhtlehuanitzin, entre otras.

Y al tiempo que los relatos son muchos y prolijos, se advierte, en cambio, que son muy escasas las fuentes pictóricas acerca del enfrentamiento entre tenochcas y tepanecas. De ahí que este trabajo se hubiera propuesto, inicialmente, aproximarse al estudio de las versiones textuales y plásticas que de esta guerra ofrecieron, por una parte, el dominico fray Diego Durán y, por la otra, el jesuita Juan de Tovar. En el proceso, sin embargo, nos percatamos de que en algunas de las láminas teóricamente alusivas a tal conflicto había elementos que no correspondían o no encajaban en el marco de aquel episodio, razón por la cual fue menester dejar de lado el análisis exclusivo sobre la guerra de Azcapotzalco e incluir estudios particulares sobre las ilustraciones, a fin de desentrañar su verdadero contenido y exponer posibles explicaciones respecto de las razones de él. En las páginas que siguen se da cuenta puntual de los resultados.

\section{LOS MANUSCRITOS}

1. La Historia de las Indias de la Nueva España e Islas de la tierra Firme de Diego Durán

Las indagaciones que sobre el pasado, costumbres y creencias de los indios realizó el dominico Diego Durán ${ }^{3}$ durante muchos años y que luego puso por

${ }^{3}$ Lamentablemente, no tenemos mucha información de la vida de fray Diego Durán. Sin embargo, lo poco que sabemos proviene de lo que él mismo apuntó sobre sí en su Historia y su Tratado de los ritos. Así afirma que nació en Sevilla hacia 1537, que siendo aún muy pequeño, «mudando sus dientes», se trasladó con sus padres a la Nueva España, a la ciudad de Tetzcoco, donde su familia radicó durante diez años. En su estancia en esta población, la familia Durán convivió con sus vecinos españoles e indios, y es muy posible que el niño Diego haya aprendido aquí el náhuatl. En 1547 los Durán se trasladaron a la Ciudad de México, y Diego tal vez hizo estudios. El 8 de mayo de 1556 ingresó a la Orden de Santo Domingo, más tarde realizó su ministerio entre los indios del Valle de Oaxaca, con incursiones frecuentes en el valle de México, Puebla y Morelos, sitios en los que fray Diego debió reca- 
escrito, entre 1570 y 1581, es el producto que hoy conocemos como Historia de las Indias.

El fin que guió sus esfuerzos fue el de compartir su conocimiento sobre los naturales entre sus hermanos de hábito para una mejor identificación de las prácticas idolátricas; no obstante, en el transcurso de la elaboración del texto, su material le fue requerido por un deudo suyo, el jesuita mestizo Juan de Tovar $^{4}$, religioso elegido para satisfacer por escrito, a su vez, la demanda informativa del célebre Joseph de Acosta, también miembro de la Compañía de Jesús, y estudioso de la historia indígena. Así que la obra de Durán —incluso antes de ser terminada - pasó por otras manos.

Para la elaboración de su obra el dominico se basó en sus recuerdos, en la consulta de informantes, en códices pictográficos con anotaciones, y en historias de síntesis tanto de indios como de españoles que participaron en la conquista. Entre sus fuentes figuran: una Relación, que le sirvió de base para su obra, a la que siglos después Robert Barlow llamó la «Crónica X» ${ }^{5}$, además de una historia mexicana, una relación de Azcapotzalco; una de Coyoacan; y

bar la información que luego incluiría en sus tratados. En 1586, Durán aparece registrado en un acta inquisitorial como intérprete de una indígena hablante de náhuatl ante el Tribunal de la Santa Inquisición. Un año más tarde su nombre vuelve a figurar en otro documento inquisitorial como denunciante de abusos del también fraile Andrés Utrilla. Falleció en 1588. Véase: Camelo y Romero Galván, 2002, vol. 1: 22-44. Máynez Vidal, 1997: 13-17.

${ }^{4}$ El parentesco entre Diego Durán y Juan de Tovar se ha documentado por la correspondencia entre este último y el padre Joseph de Acosta (1586-1587), y también por las indagaciones y estudios que sobre las obras de Tovar, Acosta y Durán han emprendido, desde 1596 hasta nuestros días, Agustín Dávila Padilla, Joaquín García Icazbalceta, José Fernando Ramírez, Eugène Beauvois, Edmundo O'Gorman o Robert Barlow. Es posible que la convivencia entre ambos autores haya sido estrecha, tanto por sus lazos familiares, como por haber coincidido en su infancia y juventud en las ciudades de Tetzcoco y México, e indudablemente porque en su vida adulta ambos se hicieron eclesiásticos. El mismo Juan de Tovar se refería a Durán como «un dominico deudo suyo». Véase: O’ Gorman, 1962: LXXVII-CVIII.

${ }^{5}$ La prolongada polémica sobre este texto se remonta al siglo XIX y arraiga en las conjeturas de José Fernando Ramírez sobre la posible existencia de una fuente en náhuatl - posteriormente traducida al castellano-, que sirvió como base para la realización de diversas obras de tradición mexica, entre las que se encontraba la Crónica Mexicana de Hernando Alvarado Tezozómoc. Véase: Alvarado Tezozómoc, 1987: 9-15.

Para 1945, ya se habían identificado cinco fuentes con evidentes similitudes estructurales: el Manuscrito Tovar, el libro VII de la Historia natural y moral de las Indias de José de Acosta, el Códice Ramírez, el volumen correspondiente a la historia de la Historia de las Indias de Nueva España e Islas de Tierra Firme de fray Diego Durán y la Crónica mexicana de Hernando Alvarado Tezozómoc. Según el dictamen de Robert Barlow, las tres primeras no serían sino variantes de una versión corta de la obra de Durán, con lo que el problema se reducía a dar con la fuente única a partir de la que se originaron las obras de Durán y Alvarado Tezozómoc. A esta obra perdida Barlow la denominó «Crónica X» y en su concepto, 
la consulta de fray Francisco de Aguilar, quien antes de formar parte de la Orden de Santo Domingo había participado en la conquista de México-Tenochtitlan ${ }^{6}$.

La organización que Durán dio a su escrito fue tripartita, cada una adicionada con pinturas, que en total suman 118 láminas. Sus enunciados y división son los siguientes:

- Tratado primero: La Historia.

- Tratado Segundo: El Libro de los ritos y ceremonias en las fiestas de los dioses y celebraciones de ellas.

- Tratado Tercero: El Calendario Antiguo ${ }^{7}$.

De estos textos, al parecer no se sacó copia. Su original, después de haber sido consultado por Tovar, debió regresar a manos de Durán, quien posteriormente lo envió a España ${ }^{8}$.

La secciones de la obra de Durán que nos interesa es la primera, la Historia, donde el autor desarrolla, en setenta y ocho capítulos cronológicamente dispuestos, una narración que inicia con disquisiciones sobre el origen de los indios y su posible identificación con una rama de las tribus de Israel, pasa por el recuento de la salida de los siete grupos nahuatlacas de Chicomoztoc y su establecimiento en el altiplano central, procede a la conquista española de Tenochtitlan y culmina con la expedición de Hernán Cortés a las Hibueras. Dentro de este apartado, el autor dedica los capítulos VIII y IX al conflicto entre tenochcas y azcapotzalcas.

debió ser escrita en lengua náhuatl por un indígena entre 1536 y 1539, e iba acompañada de dibujos. Véase: Barlow, 1990: 20-27.

6 Camelo y Romero Galván, 2002, vol. 1: 33-35. Máynez Vidal, 1997: 23-25.

7 Diego Durán escribió sus tratados en un orden distinto al que le da a su obra. Así, redactó primero su Libro de los ritos y ceremonias en las fiestas de los dioses y celebraciones de ellas, el cual terminó de escribir en 1570. Posteriormente, en 1579 elaboró su Calendario Antiguo, y por último su Historia, la cual va a dar por terminada en 1581. Véase: Camelo y Romero Galván, 2002, vol. 1: 15-49. Parte de las láminas que ilustran El Libro de los ritos y ceremonias y El Calendario Antiguo fueron recortadas de otra fuente, e integradas en estos tratados. Véase: Robertson, 1968: 340-348.

${ }^{8}$ La idea de Xavier Noguez es que al ser enviada a la península, la obra del dominico debió arribar a un convento de su orden — no a ninguna dependencia de la Corona- y que, posteriormente, al secularizarse los bienes de la Iglesia, durante el reinado de Isabel II, el manuscrito fue trasladado a la biblioteca Nacional de España, en Madrid, donde es resguardado en la vitrina 26-II. Véase: Noguez, 2012: 16. 
Es importante puntualizar que para el presente análisis decidimos utilizar dos ediciones de la obra de Durán ${ }^{9}$. La primera es la más reciente y se trata de la preparada por Rosa de Lourdes Camelo Arredondo y José Rubén Romero Galván en 2 volúmenes, salida de prensas en 2002. La segunda, es la edición digital del original de la Historia de las Indias e Islas de tierra Firme, resguardada en la Biblioteca Nacional de España. Y la razón para haber considerado esta última es que nos permite conocer la ubicación precisa de las láminas, examinarlas completas ${ }^{10} \mathrm{y}$, en consecuencia, determinar su posible relación con el texto alfabético.

2. La Relación del origen de los indios que habitan en esta Nueva España según sus historias de Juan de Tovar

Por su parte, el ya mencionado Juan de Tovar fue autor de una Relación del origen de los indios que habitan en esta Nueva España según sus historias. Tratado de los ritos y ceremonias y dioses que en su gentilidad usaban los indios de esta Nueva España. Se ha referido también que realizó el trabajo por petición de su hermano Joseph de Acosta, quien por la misma época recogía información para su propia Historia Natural y Moral de las Indias. Gracias a la correspondencia que sostuvo Tovar con Acosta entre 1586 y 1587, sabemos que para la confección de su Relación, Tovar recurrió a sus propias evocaciones acerca de lo que, años antes, «averiguó y trató muy despacio» sobre el pasado indígena con miras a escribir una Primera Relación que le solicitó el virrey Martín Enríquez de Almanza ${ }^{11}$, y también hizo referencia directa al aprovechamiento de la obra de «un dominico» que como indiqué anteriormente, por menciones y estudios ulteriores, podemos identificar, fuera

9 De esta obra conocemos las siguientes ediciones: una incompleta de la Historia que publicó en 1867 José Fernando Ramírez. En 1880 Gumecindo Mendoza, director del Museo Nacional, editó la parte restante de las obras. Ángel María Garibay dispuso en 1967 la segunda edición de la Historia en tres libros que integran la crónica, organizada cronológicamente, según las fechas de redacción, incluye reproducciones fotográficas a color de las pinturas. En 1999 Rosa Camelo y José Rubén Romero Galván publican la obra en su totalidad, tomando como base las ediciones de 1867-1880 de José Fernando Ramírez, la versión paleográfica se debe a González Vera y las reproducciones de las láminas a Jules Desportes. Véase: Camelo y Romero Galván, 2002, vol. 1: 17-18. Máynez Vidal, 1997: 32-37.

10 En las ediciones de Ángel María Garibay y de Rosa Camelo y José Rubén Romero Galván las imágenes no son íntegras, sino fragmentarias.

11 Esta primera relación versaba sobre los reinos de México, Acolhuacán y Tlacopan, y su paradero se desconoce. Véase: Tovar, 1972: 3-4. García Icazbalceta, 1954: 491-492. 
de toda duda, como la Historia de las Indias de la Nueva España e Islas de la Tierra firme del referido fray Diego Durán ${ }^{12}$.

Otro texto del que se sirvió Tovar, pero que no se menciona explícitamente en sus cartas, es el libro de La conquista de México del franciscano Bernardino de Sahagún, en su última versión reformada de 1585 y cuyo uso fue identificado por Luis Leal en $1955^{13}$. Siendo así, el propio Sahagún debió entregársela a Tovar, poco tiempo después de terminarla, a la vista de que el jesuita dispuso apenas de poco menos de un año para terminar su segunda relación, es decir, la que iba destinada a Acosta14.

Juan de Tovar organizó su trabajo en dos partes, con sus respectivas pinturas:

- La primera, una Relación que contiene la narración sobre el pasado de los indios a través de los relatos indígenas, tomando como eje principal el pasado del pueblo mexica, a la que tituló Relación del origen de los indios que habitan en esta Nueva España según sus historias, en la que centramos nuestra atención aquí.

- La segunda, un Tratado que describe las costumbres civiles y religiosas de los indios antes de la conquista española y relata su ulterior introducción del cristianismo. Esta parte fue titulada Tratado de los ritos y ceremonias y dioses que en su gentilidad usaban los indios de esta Nueva España.

Esta Segunda Relación el jesuita la plasmó en dos versiones realizadas en el siglo XVI, una, posiblemente destinada a su propia corporación religiosa y la otra para entregarla a Joseph de Acosta. Ambas presentan diferencias físicas entre si $^{15}$, que se perciben en la organización del texto, en la ubicación de las

12 Entre los autores que aluden a la filiación entre estas obras y sus autores se encuentran Agustín Dávila Padilla, Joaquín García Icazbalceta, José Fernando Ramírez, Eugéne Beauvois, Edmundo O'Gorman, Robert Barlow y José Rubén Romero Galván. Véase: O’Gorman, 1962: LXXVII-CVIII. Dávila Montoya, 2005: 44-60.

13 Leal, 1955: 190-191.

14 La última versión reformada de la Conquista de México que Sahagún elaboró en 1585, fue descubierta por Carlos María de Bustamante poco tiempo después de haber publicado la primera edición de la Historia General de las cosas de la Nueva España de Sahagún, mandándola publicar en 1840 como una obra que probaba la aparición de la Virgen de Guadalupe. Véase: Sahagún, 1840: 247.

15 Creemos que las variantes obedecen a los distintos fines a que debían servir los manuscritos. El ejemplar que conocemos como Manuscrito Tovar debía servir de fuente a Joseph de Acosta para su historia y sería llevado a Europa, por lo que su confección fue objeto de un mayor cuidado y gasto: se encomendó su elaboración a un tlacuilo y se empleó una amplia 
pinturas y en el anexo documental, aumentado en diferentes épocas por otras manos. Adicionalmente, las obras exhiben también diferencias internas, que van desde omisiones o cambios sintácticos en el relato, hasta variantes en el contenido de las pinturas ${ }^{16}$.

\section{TAbla 1: Cuadro de Diferencias entre el Manuscrito ToVAR Y EL CÓDICE RAMÍREZ}

\begin{tabular}{|c|c|}
\hline Manuscrito Tovar & Códice Ramírez \\
\hline $\begin{array}{l}\text { Escrito en español utilizando la página ple- } \\
\text { na, con una extensión de } 82 \text { folios de texto, } \\
\text { y } 39 \text { láminas, está conformado por: } \\
\text { - la correspondencia epistolar entre Tovar y } \\
\text { Acosta; } \\
\text { - la Relación del origen de los indios...; } \\
\text { - El Tratado de los ritos y ceremonias...; } \\
\text { - } 28 \text { láminas numeradas de dos en dos con } \\
\text { dibujos a la acuarela, que ilustran la Re- } \\
\text { lación y el Tratado y que se ubican al } \\
\text { final del Tratado; } \\
\text { - Y el Calendario de Tovar que cuenta con } \\
\text { una extensión de once láminas*. }\end{array}$ & $\begin{array}{l}\text { Manuscrito anónimo, con una distribución } \\
\text { en dos columnas, de las cuales sólo está } \\
\text { escrita la del lado izquierdo. Cuenta con una } \\
\text { extensión de } 269 \text { fojas y } 32 \text { láminas, está } \\
\text { conformado por: } \\
\text { - La Relación del origen de los indios...; } \\
\text { - El Tratado de los ritos y ceremonias...; } \\
\text { - } 30 \text { dibujos realizados a pluma y tinta en } \\
\text { página plena e intercaladas en el texto de } \\
\text { la Relación y el Tratado con sus respec- } \\
\text { tivos encabezados descriptivos; } \\
\text { - Y Tres fragmentos de textos con dos lá- } \\
\text { minas que se creen están asociadas a } \\
\text { ellos. }\end{array}$ \\
\hline
\end{tabular}

* En el Calendario Tovar se describe cada una de las dieciocho fiestas y ceremonias que realizaban los mexicas antes de la conquista; además indica el cómputo de los días según el calendario mexica y su equivalente en el cristiano.

paleta de colores a la acuarela; figuran dos láminas por hoja y se dispusieron todas juntas al final del tratado de los ritos que precede la Relación. En contrario, la versión que conocemos como Códice Ramírez, se elaboró con un presupuesto menor, sus láminas se elaboraron a pluma y tinta, ocupan la hoja plena, y se les intercaló en el texto, acompañándolas con pies de imagen que describen su supuesto contenido y que, en algunos casos, se encuentran en la misma foja que la pintura y en otros no. Sólo el anverso de la primera lámina de la Relación fue utilizado, continuando en ellas el relato alfabético. La austeridad de estas láminas y su ubicación nos llevan a pensar que tanto las pinturas como el texto alfabético pudieron haber sido elaborados por la misma mano, debido a que no se juzgó necesario derrochar lujos en un ejemplar destinado a satisfacer un deseo personal o una necesidad informativa de la Compañía, que centraba su atención en el texto alfabético para ampliar el vocabulario náhuatl de los ministros dedicados a tareas evangélicas, interés que se encuentra plasmado también en las pinturas, las cuales contienen anotaciones referentes a los nombres de los atuendos usados por los personajes.

16 Lafaye, 1970: 359-371. Dávila Montoya, 2005: 63-78. 
Por su contenido, el Manuscrito Tovar fue identificado posteriormente como el ejemplar de la Segunda Relación, que Juan de Tovar entregó a Joseph de Acosta entre 1586 y 1587, quien posteriormente anexó al texto las cartas y el calendario que le envió su compañero de orden. El rastro del manuscrito estuvo perdido por largos años y se volvió a saber de él en 1856, cuando Sir Thomas Phillips divulgó que formaba parte de su biblioteca personal ${ }^{17}$. Por otro lado, el ejemplar que conocemos como Códice Ramírez apareció también en 1856, en la Biblioteca del convento mayor de San Francisco de la Ciudad de México, donde lo halló José Fernando Ramírez, comisionado para inventariar los libros y papeles resguardados en la biblioteca y archivo conventuales.

Cabe señalar que ambas versiones de la Relación de Tovar carecen de capitulado, aunque en las dos la secuencia narrativa es cronológica en el tratamiento de diversos temas: el origen de los indios, la salida de los siete grupos nahuatlacas de Chicomoztoc, su establecimiento en el altiplano central, el episodio de la llegada de las huestes cortesianas y su huida de Tenochtitlan. El episodio de la confrontación entre Azcapotzalco y Tenochtitlan ocupa, en los dos casos, dieciséis páginas y una lámina.

\section{Los relatos de la guerra de Azcapotzalco de Diego Durán y JuAN DE Tovar. Similitudes y DifERENCIAS}

Los recuentos del pasado mexica que en caracteres latinos plasmaron Diego Durán y Juan de Tovar incluyen, según se ha apuntado, el enfrentamiento entre los tenochcas y los tepanecas de Azcapotzalco. Ambos autores coinciden en que tal fue el suceso que marcó la liberación del pueblo mexica del yugo tepaneca, pues les granjeó el respeto de los pueblos comarcanos a la vista de la capacidad bélica que desplegaron para vencer «al supremo lugar a quien reconocía toda la tierra ${ }^{18}$ y también señaló el comienzo de su carrera expansionista a través de las armas.

17 En 1860 el propio Phillips hizo de él una edición deficiente e incompleta. Actualmente el manuscrito se encuentra en la John Carter Brown Library, Rhode Island, Estados Unidos. Existen tres ediciones completas del Manuscrito de Phillips, la primera fue la preparada por Jaques Lafaye en 1972, quien hizo acompañar las láminas que conforman el Manuscrito Tovar con la descripción de su contenido, y una relación de su correspondencia con las planchas del Códice Ramírez y de la Historia de Durán. La segunda es la de José J Fuentes del Pilar, con transcripción al castellano moderno de Susana Urraca Uribe, publicada en 2001. Para el presente estudio nos servimos de la mencionada edición de Lafaye, realizada en 1972.

18 Tovar, 1972: 34. Durán, 2002: 70. Códice Ramírez, 1987: 52. 
Los relatos del dominico y del jesuita no parecen diferir ni en contenido ni en forma, lo que nos lleva a asentar que el recuento de Tovar de tal episodio se apegó al que ofrecía la Historia de Durán. No se deduce otra cosa de los distintos pasajes, así cuando se precisa el deseo de los tenochcas de alzarse en armas contra el dominio tepaneca, para cuyo efecto hicieron la estratégica designación de Chimalpopoca como nuevo tlahtoani de Tenochtitlan. Chimalpopoca era hijo del señor Huitzilihuitl de Tenochtitlan, y nieto de Tezozomoc, tlahtoani de Azcapotzalco. En este sentido, se infiere que los tenochcas buscaban valerse del amor del abuelo hacia su nieto para provocar la división interna de los pueblos tepanecas.

Los dos relatos consignan actos de provocación protagonizados por ambos centros y reproducen por igual un par de acontecimientos relevantes que agudizarían las tensiones entre tenochcas y tepanecas: el primero, la petición arrogante y ofensiva que hicieron los primeros a los segundos de facilitarles mano de obra y materiales para abastecerse del agua de Chapultepec, situación que sirvió para que los señores principales de este centro, los tlatoque de Tlacopan y Coyoacan, se conjuraran en contra de Tenochtitlan, y el segundo el homicidio de Chimalpopoca, cometido en su propio palacio, mientras dormía, por agentes tepanecas, luego de la muerte de su abuelo Tezozomoc, consumido por la vejez y la tristeza de saber que su consejo había decidido matar al nieto para castigar su atrevimiento. Coinciden igualmente en la confusión que experimentaron los tenochcas al descubrir el cadáver de Chimalpopoca, consignan luego el nombramiento de Itzcoatl, el fallido intento mexica de restablecer la paz, a través de la diplomacia, y la final declaración de guerra. También mencionan la promesa de «la gente común tenochca» de servir a los miembros de la casa principal tenochca si vencían a Azcapotzalco, la conflagración y el reparto del botín que siguió al triunfo de Tenochtitlan.

A pesar de estas notorias semejanzas, también es obvio que Tovar no se limitó a copiar textualmente a Durán, pues hay notas y detalles que el dominico destaca en su Historia y que el jesuita, en cambio, pasa por alto o los refiere de manera breve. Fray Diego subraya, por ejemplo, que el emplazamiento del islote donde se fundó Tenochtitlan «no era suyo, pues era sitio y término de los de Azcaputzalco, de los de Tezcucco, y de los de Colhuacan», lo que sujetaba a los tenochcas a esas tres cabeceras, con las que debería sostener negociaciones políticas. En otra parte subraya que Itzcoatl era hijo natural de Acamapichtli y de una esclava de Azcapotzalco, hecho que induciría a pensar que su elección obedeció al interés tenochca de buscar la paz, de prestar nuevamente obediencia a los tepanecas y ganarse su favor a través del parentesco. Añade que 
... al nombramiento de Itzcoatl asistieron principales de Tezcuco, quienes se vieron contentos con la elección, ya que Ixtlilxochitl, que entonces reinaba en Tezcuco, padre de Nezahualcoyotl, estaba casado con una hermana del dicho nuevo rey Itzcoatl, con cuyo favor y ayuda fue Nezahualcoyotl restituido en su reino, después de haber andado huyendo de los tepanecas, que le habían querido matar $[\ldots]^{19}$.

Llama igualmente la atención la identificación de Maxtlatzin, señor de Coyoacan, y Aculnahuacatl, señor de Tacuba, como cabecillas de la conspiración contra los mexicas tenochcas, y su inesperada ausencia en la guerra, a la que debieron haber acudido del lado de Azcapotzalco, en tanto miembros de la nación tepaneca. Y, finalmente, también hay que destacar la mención de Xoconochnopaltitlan como el escenario bélico.

Toda esta información que aporta Durán y que Tovar soslaya u omite perfila diversos aspectos, como la sujeción de Tenochtitlan a Azcapotzalco, Culhuacan y Tetzcoco. Por otro lado, la enumeración de los señores que ofrece la Historia permite identificar la red de relaciones políticas establecida a través de matrimonios entre las principales casas tenochcas y tepanecas y comprender el importante papel que desempeñaron en la elección de Itzcoatl y en la obtención de lealtades para ambos bandos en el momento de la guerra.

Por su parte, al referirse al tiempo de la sujeción de los tenochcas, en sus dos versiones Tovar sólo reconoce el sometimiento a Azcapotzalco y Culhuacan, (pero no a Tetzcoco), ciudades con las que negoció políticamente algunas mejorías en su condición, logrando que casi desapareciese en relación con Culhuacan, a través del nombramiento de Acamapichtli, nieto de Nauhyotl, tlahtoani de dicho centro. En contrario, respecto de Azcapotzalco, y por mucho que la situación hubiera mejorado con el nacimiento de Chimalpopoca, el jesuita es claro al asentar que la única vía posible de liberación tenochca era la bélica, por ello tenían interés en ejercitarse «en el arte militar para el intento que tenían siempre de librar su ciudad por fuerza de armas» ${ }^{20}$.

Una posible explicación de la omisión de Tetzcoco en este recuento es que Tovar haya asumido que, para el momento de la guerra contra Azcapotzalco, Tetzcoco ya había venido a menos, para ubicarse más como un igual que como

19 Durán, 2002: 73. Tovar, 1972: 36. Durán, 2002: 49. Durán señala que a las exequias de Chimalpopoca asistió, como tlahtoani de Tetzcoco, Ixtlilxochitl, cosa imposible, pues había sido asesinado por los tepanecas años antes. Quien debió asistir fue su hijo, Nezahualcoyotl, que por entonces ya había abandonado Tetzcoco, a causa de la persecución tepaneca. Véase: Códice Xólotl, lámina VI. Torquemada, 1986, cap. XX. Alva Ixtlilxóchitl, Sumaria Relación de las cosas de Nueva España, 1975: 342-343.

20 Tovar, 1972: 32. 
un superior de Tenochtitlan, toda vez que su tlahtoani Ixtlilxochitl, había perecido a manos de los tepanecas, y que su hijo, Nezahualcoyotl, era objeto de persecución y había sido despojado de su pueblo.

Que el jesuita pase por alto la mención de los nombres de los señores de Culhuacan, Tetzcoco y Azcapotzalco luego de la muerte de Tezozomoc, podríamos considerarlo producto de un descuido, que tampoco sería raro, puesto que su interés primordial era llamar la atención del lector en los personajes tenochcas, ya que sobre ellos versaba su relato.

\section{La lámina 11 de la Historia de Durán: ¿Coyoacan o AzCAPOTZALCo?}

Al analizar las representaciones iconográficas del enfrentamiento entre tenochcas y tepanecas que acompañan a las tres obras que venimos estudiando, saltan a la vista varias cuestiones. Empecemos por las que se advierten en la Historia de Durán. Pese a que el dominico reconoce palmariamente la importancia de dicha guerra, parecería que no se interesó en incluir ninguna ilustración de ella, ni en el comienzo ni a lo largo de su relato del episodio. Sin embargo, hay una lámina, la 11, alusiva a la guerra contra pueblos tepanecas, que hace las veces de lindero entre el capítulo IX ("De la elección del rey Itzcoatl y de cómo puso en libertad la ciudad de México y de lo [de] más en su tiempo Sucedido"), y el capítulo X ("De cómo los tepanecas de Cuyuacan movieron guerra contra los mexicanos y de cómo fueron vencidos") ${ }^{21}$.

Tradicionalmente, se ha dado por hecho que esta pintura ilustraba el enfrentamiento entre los tepanecas de Coyoacan y los tenochcas; así lo creyó en el siglo XVI Juan de Tovar, quien incluso la copió como una representación de "la guerra contra Coyoacan" en su propia Relación; y así la dieron por buena en el siglo XIX José Fernando Ramírez y en el XX Ángel María Garibay, Rosa Camelo y José Rubén Romero ${ }^{22}$. Con ello se sentó un canon secular que ningún especialista ha objetado hasta hoy, pero que nosotros nos proponemos revisar en las líneas que siguen.

21 El capítulo IX refiere los inútiles esfuerzos diplomáticos tenochcas para restablecer la paz, el inicio de la guerra, los premios que repartió Itzcoatl entre su gente luego de vencer a Azcapotzalco y las nuevas condiciones de los tepanecas como sujetos de Tenochtitlan. El X relata las provocaciones del señor de Coyoacan a los tenochcas como una tentativa de vengar la derrota y la final destrucción de Azcapotzalco.

22 José Fernando Ramírez, Ángel María Garibay, Rosa Camelo, y José Rubén Romero se dieron a la labor de preparar las publicaciones que tenemos de esta obra. 
Figura 1: LÁmina 11, en Durán, Historia DE LAS INDIAS DE NUEVA ESPAÑA E ISLAS DE LA TIERRA FIRME, MÉXICO, CA. 1579

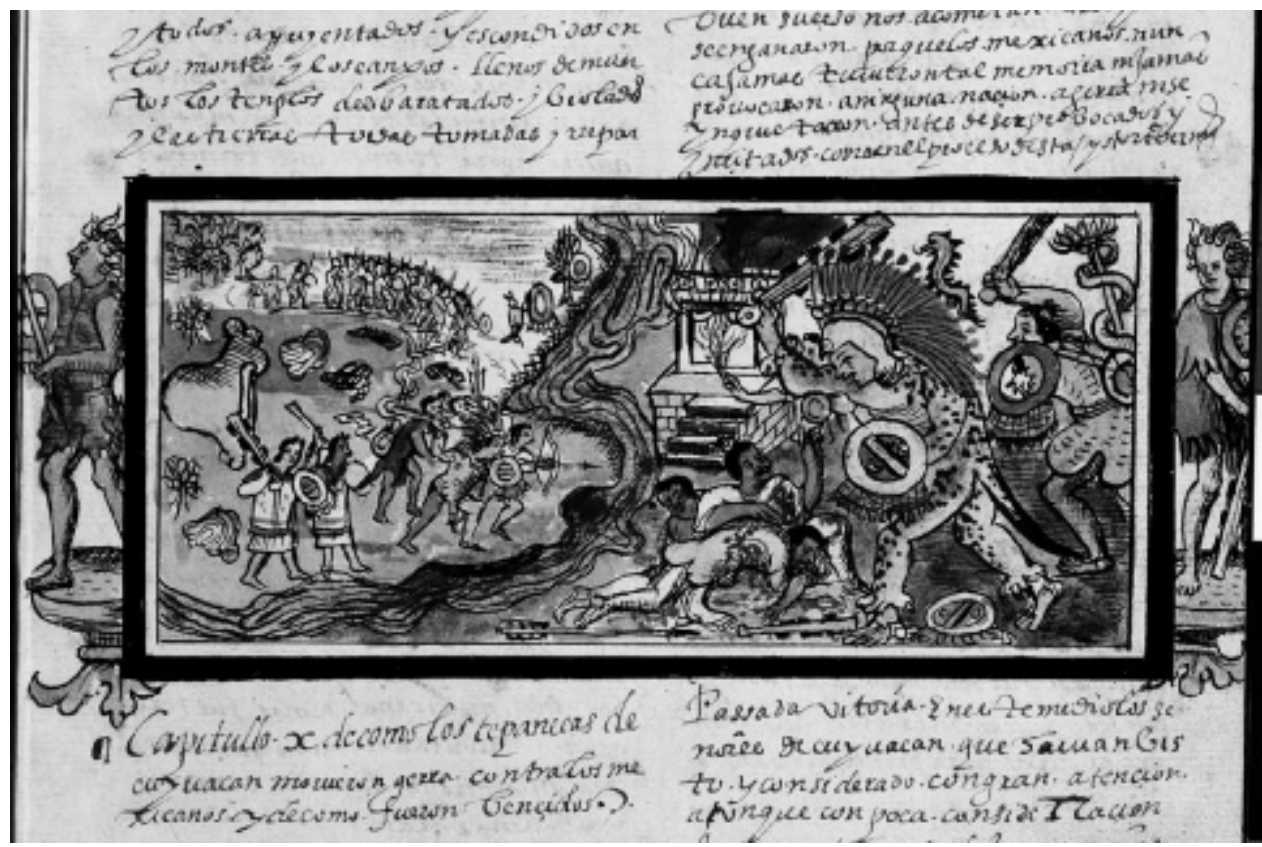

Foto: Fondo Reservado, Sala Cervantes, Núm. Vitr/ 26/11, Biblioteca Nacional de España, Madrid, f. 98 r.

Al igual que las otras 63 pinturas que acompañan la Historia de Durán, la lámina 11 está elaborada a la acuarela, con una mixtura de técnicas europeas (el uso de la perspectiva, el paisaje, la proporción y el volumen en las figuras) e indígenas (la representación de antropónimos y topónimos, de vestimentas y armas asociadas a la guerra y otros convencionalismos mesoamericanos, como el templo quemado y sus decoraciones).

En un orden de izquierda a derecha, y de arriba hacia abajo, encontramos que el suceso bélico que refiere está conformado por cuatro escenas o unidades temáticas, organizadas de manera consecutiva. La primera de ellas, ubicada en el ángulo superior izquierdo, consta de tres elementos: un bosque, un grupo de guerreros ordenados en forma de batallón que portan escudos y lanzas o flechas (el grupo marca su movimiento de izquierda a derecha, a través del desplazamiento de tres guerreros pintados en perspectiva sobre un camino en dirección al grupo), y por dos árboles o nopaleras, en las que, 
mediante el recurso de aumentar el tamaño de la imagen, se trata de destacar unas tunas de color rojo. Hacia este tercer elemento se dirigen los guerreros. En nuestra opinión, estas nopaleras podrían ser símbolos alusivos al lugar, es decir, representarían un glifo topónimo, cuya interpretación podría estar relacionada con las tunas, nochtli, y los nopales, nopalli. Y aquí viene al caso señalar que no hay ningún lugar de estas características en el relato de la batalla de Coyoacan ${ }^{23}$, pero sí, en cambio, en la descripción que ofrece Durán de la guerra contra Azcapotzalco, según veremos.

Y así mandó [Tlacaelel] que todos siguiesen a su capitán, acudiendo a donde viesen haber más necesidad y que ninguno echase pie adelante, sino fuese mandado. Y con esto empezaron a marchar hacia Azcapotzalco con mucho orden y concierto. Llegados a un lugar que se dice Xoconochnopaltitlan, los de Azcapotzalco les salieron al encuentro con buena ordenanza ${ }^{24}$.

Figura 2: Unidad temática 1. LÁMina 11, en DURÁN, Historia DE LAS INDIAS DE NUEVA ESPAÑa E ISLAS DE LA TIERRa FIRME, MÉXICO, CA. 1579

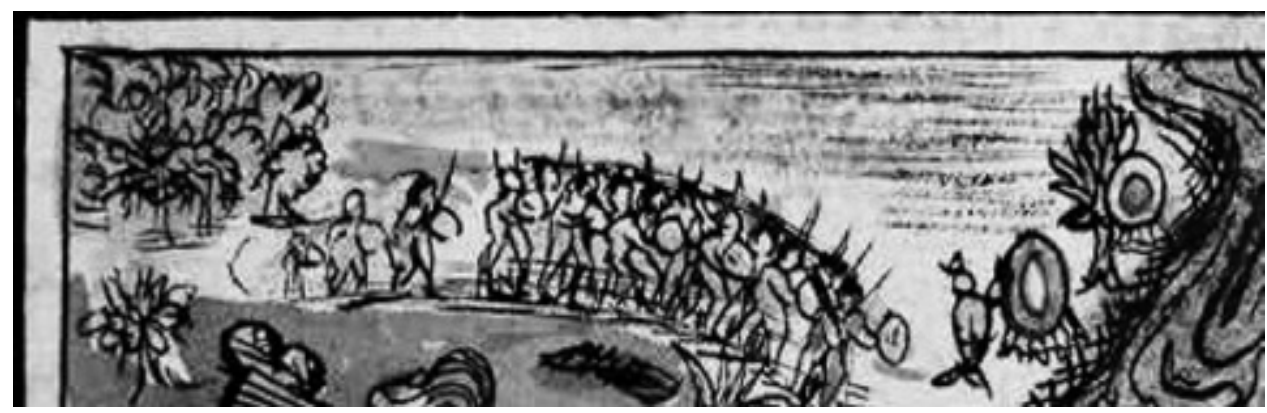

Foto: Fondo Reservado, Sala Cervantes, Núm. Vitr/ 26/11, Biblioteca Nacional de España, Madrid, f. 98 r.

La palabra «Xoconochnopaltitlan» puede traducirse como «al lado de los nopales de tunas agrias» ${ }^{25}$, de lo que se desprende que podría ser el sitio re-

23 Ver Durán, 2002: 127.

24 Ibidem: 80.

25 Xoconochnopaltitlan viene de: $\{$-tlan $\}$ locativo «al lado de», \{-ti $\}$ ligadura, \{nopalli- $\}$ «nopal», \{noch\} «tuna», \{xoco-\} «agrio», que podría traducirse como: «Al lado de los nopales de tunas agrias». Es decir, al lado de la nopalera de xoconostles. Véase: Molina, 2001: 72v, 73v y 160v. Launey, 1992: 120. 
Figura 3: Ubicación aproximada de XoconochnopalyaCaC al PONIENTE DE LA CUENCA DE MÉXICO

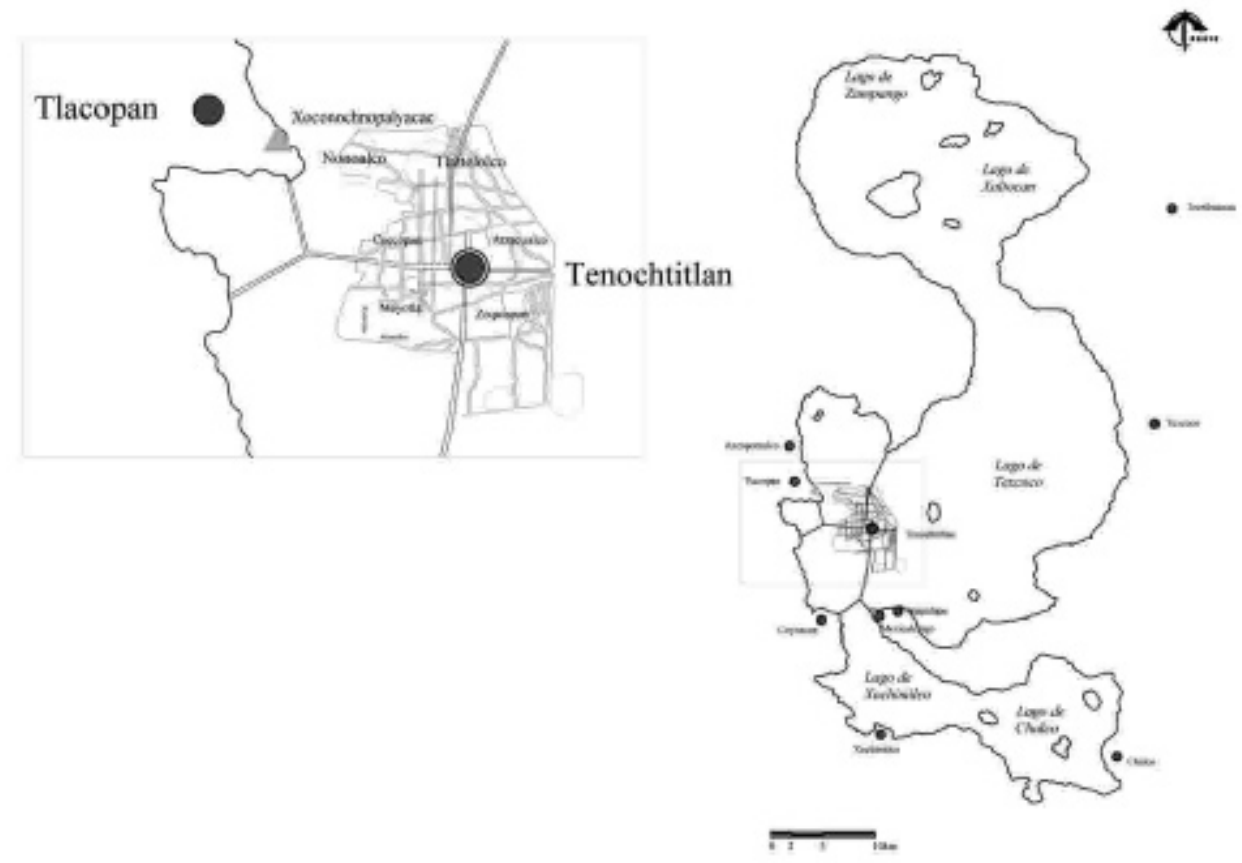

Mapa elaborado por Edgar Pineda Santa Cruz para el presente artículo.

presentado en esta primera unidad temática, Xoconochnopaltitlan, el emplazamiento donde se encontraron las huestes tenochcas con las azcapotzalcas. Por otro lado, no puede tratarse del glifo de Tenochtitlan, pues los nopales que figuran en esta lámina carecen de la piedra de la que nace la planta del glifo representativo de esta ciudad. Adicionalmente, en su Crónica Mexicana, Hernando Alvarado Tezozómoc se refiere al lugar de encuentro de las fuerzas mexicas y azcapotzalcas como «Xoconochnopalyacac», al que describe como un lugar de guardia tepaneca, con la que tuvo un encuentro Tlacaelel cuando regresaba de declarar la guerra a Azcapotzalco: «[después de haber sido afrentados por Tlacaelel] le dieron alcance los tepanecas y le comenzaron a dar cuchilladas en la cabeza, puesto el morrión, o celada dorada trayendo por el agua, y así vino a dar en Nonohualco ${ }^{26}$. Una probable traducción del vocablo Xoconochnopalyacac que emplea Tezozomoc es «en la punta de los nopales

26 Alvarado Tezozómoc, 1987: 246-247. 
de tunas agrias ${ }^{27}$. Finalmente, cabe hacer notar que Pedro Carrasco se ha referido también al sitio denominado «Xoconochnopaltitlan, Xoconochnopalyacac, o Xoconochyacac» como un punto intermedio entre el área de Tenochtitlan y Azcapotzalco ${ }^{28}$, del que, además, puntualiza en una nota que se le ha mencionado específicamente en relación con la guerra contra Azcapotzalco, junto con Nonoalco, Mazatzintamalco y Popotlan ${ }^{29}$.

A pesar de tales corroboraciones, no podemos dejar de advertir que el topónimo ofrece problemas complejos para su ubicación definitiva. Y viene al caso indicar esto porque el cronista chalca Domingo Francisco de San Antón Muñón Chimalpahin usa el mismo sustantivo para referirse a un sitio que se localiza en otra parte muy distinta, al sur de Tenochtitlan (véase figura 4):

Auh niman axcan ypan lunes. yc XXIX. de noviembre de 1604. años.

Netequimacoc. in mexico. in Tlatilolco. yhuan yn nohuian sojetos. huel mocencauh yn niman quipehualtique in mexica in ye quiteca yancuic tetenamitl. yn tlalmantli nohuian [39 recto]

Motatacac yn nican tlaxillacalpan. Sant. Juan, yn calzolli. moxixitinin. yhuan yn ixquich huexotl mochi motlaz. ynic tlaquauhtzotzonaloc. Oncan peuh yn xolloco. St. Antonio. Abbad. oztocaltitlan in yc mochihua in ye moteca yancuic tetenamitl yc zanompa on tlantica ${ }^{30}$. Yn xoconochnopalyacac yn amanalcopa yc quitzacuillique yn atl. ypampa yn cenca hual pexontivallaquia ynihtic ciudad- ynic yetla apachohua camochitepeatl ynoncan hual momana ahuatzalpan. auh ynic tetequimacoc.
Y luego el lunes XXIX de noviembre del año 1604. Se distribuyeron el trabajo en Mexico, en Tlatilolco y en todos los sujetos. Mucho se prepararon, luego los mexica empezaron ya a poner el nuevo muro de la ciudad de tierra aplanada. [39 recto] De todas partes cavaron aquí en el barrio de San Juan, [en donde] las casuchas se cayeron. Entonces, todos los sauces todos se derribaron para que fueran martillados con dureza. Allí comenzó en Xolloco, en San Antonio Abad Oztocaltitlan, se construye, se extiende el nuevo muro de piedra, precisamente allá se acaba en Xoconochnopalyacac, por Amanalco. Con ello, ellos atajaron el agua, por causa de ella [del agua], mucho venía a llenarse el interior de la ciudadhasta anegarla, mucha agua de la sierra desde Ahuatzalpan se estancaba hacia acá.

27 Xoconochnopalyacac viene de: $\{-c\}$ locativo que se traduce como «en», \{yaca- $\}$ «nariz o punta», \{nopal\} «nopal», \{noch-\} «tuna», \{xoco-\} «agrio», que podría traducirse como: «En la punta de los nopales de tunas agrias». Véase: Molina, 2001: 30v, 72v, 73v y 160v. Launey, 1992: 115-116.

28 El sitio llamado Xoconochnopaltitlan, Xoconochnopalyacac, o Xoconochyacac [está] en el área entre Tenochtitlan y Azcapotzalco. Véase: Carrasco, 1999: 113.

29 Ibidem: 452.

30 Coincidimos con Rafael Tena en que la palabra tlantica se traduciría como «se denta, o es dentado». Aunque también podría haberse tratado de «tlamtica», que se traduciría «se acaba». Ver Chimalpahin Cuauhtlehuanitzin, 2001: 98-99. 
Ynipan yzquialtepetl. Omoteneuh. yn chinanpanecatl. cahuelixquich nican quichihuaco. Yn tequiuh. Yn iccen chinampanecatl //
A causa de que se repartió el trabajo, aquí en el altepetl se nombró a los chinanpanecas, a que todos los chinampanecas vinieran aquí a hacer su trabajo para siempre ${ }^{31}$.

Figura 4: Ubicación MERIDIONAL DE XoconochnopalyaCAC, SEGÚN LO DICHO POR ChIMALPAHIN EN SU DiaRIO FOL. 38v-39R

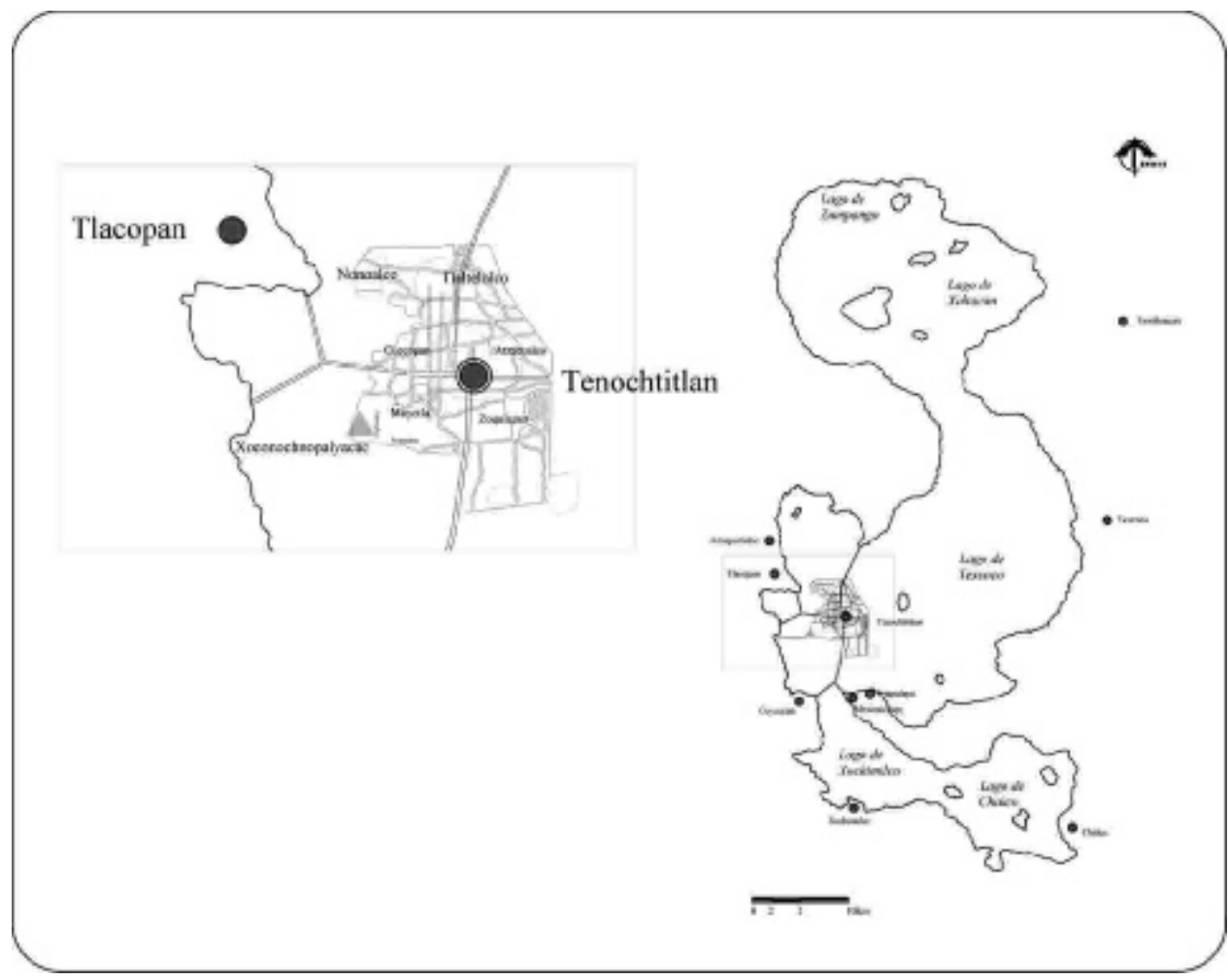

Mapa elaborado por Edgar Pineda Santa Cruz para el presente artículo según la ubicación de Xoconochnopalyacac dada por Chimalpahin.

31 Chimalpahin Cuauhtlehuanitzin, Diario de Don Domingo de San Anton Muñón Chimalpáhin, 1579-1660, Biblioteca Nacional de Francia, Departament des Manuscrits Mexicain, 220 Manuscrito, 284 folios, fol. 38v-39r, traducción Alejandra Dávila. 
Esta referencia geográfica de Xoconochpalyacac, en el barrio de Moyotla, coincide con la mención de un término al que llama Xoconochco, Juan Bautista en sus Anales:

El lunes cinco de mayo [1567] entonces terminaron la gente de todos los pueblos que vinieron a limpiar los canales; San Lázaro, la parte exterior de la carcel y Tecpancaltitlan, Xoconochco y Xolloco, que es a donde se dirige el canal, en todas partes se arregló ${ }^{32}$.

Xoconochco puede traducirse como «entre tunas agrias, o en el lugar de las tunas agrias $\rangle^{33}$. Conviniendo ambos autores en que existía un lugar alusivo a las «tunas rojas» en la parte sudoccidental de la isla. Ciertamente, no podemos descartar la posibilidad de que se trate de un lugar homónimo.

Sin embargo, en su Tercera Relación, Chimalpahin asevera que la guerra entre Tenochtitlan y Azcapotzalco comenzó o se llevó a cabo en el antiguo barrio tenochca de Cuepopan ${ }^{34}$, que cae al noroeste de Tenochtitlan.

Volviendo al análisis de la lámina XI, su segunda unidad temática se ubica en la parte inferior izquierda y comprende tres elementos: el primero, la figura de un cerro a la usanza indígena que podría representar un segundo topónimo, acaso alusivo al altepetl de Tlatelolco. El segundo es la representación de dos personajes ataviados con huipil, así que se diría que se trata de mujeres, pero que, no obstante, empuñan armas: chimalli y macahuitl. Su peculiar representación inevitablemente nos remite a los relatos tlatelolcas que afirman que, en momentos de gran peligro para la existencia de su grupo (como el enfrentamiento contra los tenochcas y la conquista española), participaron mujeres armadas de chimalli y macahuitl, que incluso hicieron cautivos $^{35}$. Desde luego, la guerra contra los tepanecas de Azcapotzalco entraba en tal clasificación de riesgo, así que bien podría tratarse de personajes femeninos que combaten. Otra posibilidad es que estas figuras con huipil aludan

32 Bautista, 2001: 163.

33 Xoconochco viene de: $\{-c o\}$ locativo que se traduce como «en o entre», \{noch- $\}$ «tuna», \{xoco-\} «agrio», que podría traducirse como: «Entre tunas agrias, o en el lugar de las tunas agrias». Véase: Molina, 2001: 73v y 160v. Launey, 1992: 115.

34 Chimalpahin Quauhtlehuanitzin, 1997: 139.

35 Véase: Anales de Tlatelolco, 2004: 27-29 y 113. El relato de la guerra de Tlatelolco de los Anales de Tlatelolco congenia en cierta manera con la versión de la guerra contra Tlatelolco de la Crónica Mexicana de Hernando Alvarado Tezozómoc y con la lámina 9 del Manuscrito Tovar, que lleva como título "La guerra de Azcapotzalco" pero que por su composición, topónimos y antropónimos podemos identificar como la batalla contra Tlatelolco, ya que las tres presentan a figuras femeninas en actitud belicosa. Véase: Alvarado Tezozómoc, 1987: 392. Tovar, 1972: 243, pl. 3. 
Figura 5: UNIDAD TEMÁTICA 2, LÁMina 11, EN DURÁN, HiSTORIA de laS INDIAS DE NUEVA ESPAÑa E ISLAS DE LA TIERRA FIRME, MÉXiCO, CA. 1579

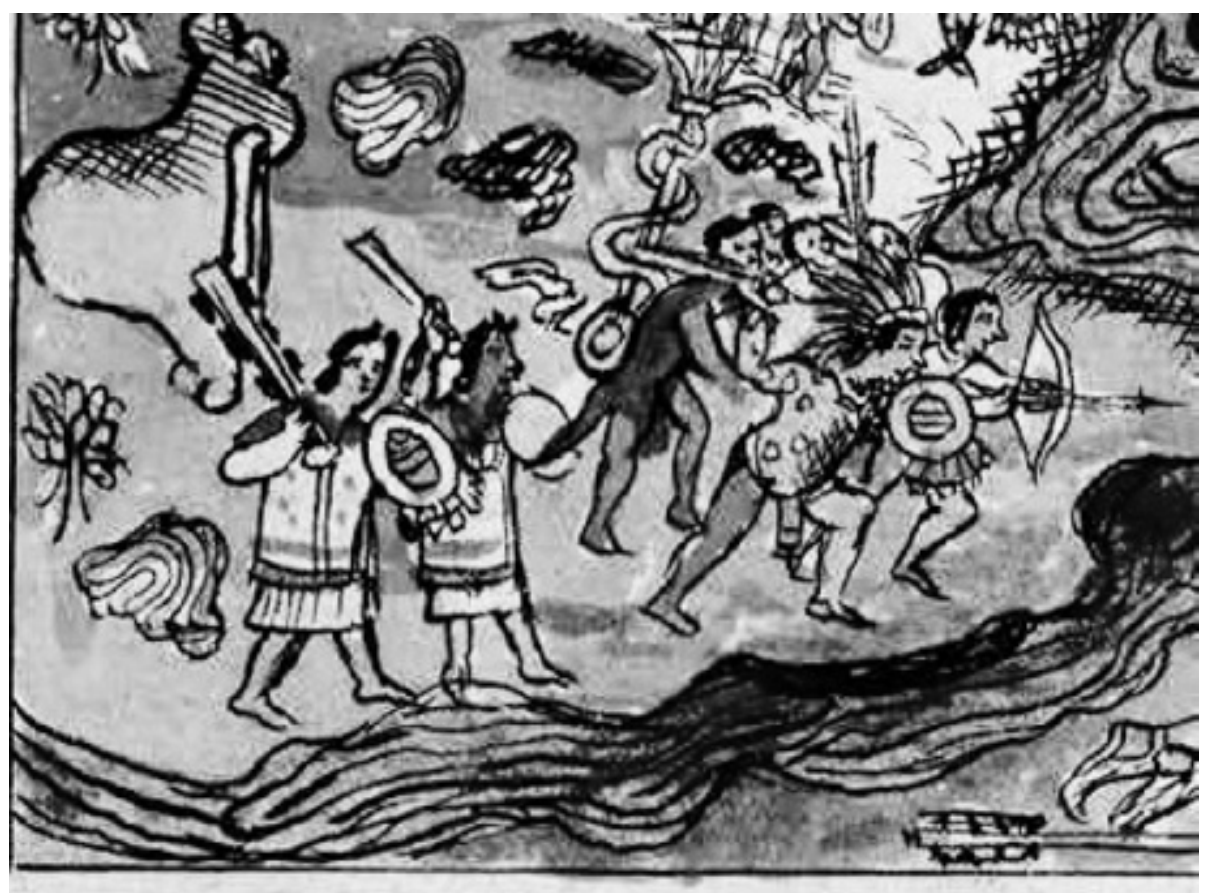

Foto: Fondo Reservado, Sala Cervantes, Núm. Vitr/ 26/11, Biblioteca Nacional de España, Madrid, f. 98 r.

al insulto que el señor tepaneca Maxtla hizo a los tenochcas al regalar a sus embajadores con atavíos femeninos ${ }^{36}$. Como sea, a ambos personajes los antecede un grupo de guerreros que lleva flechas en ristre y adelanta su chima$l l i$, además de una tercera figura que porta en la espalda un estandarte, que podría ser indicativo de que su señor estaba en entre ellos, o bien, que él

36 Sobre esta afrenta existe ambigüedad respecto del momento preciso en que se produjo. Por una parte, relatos como la Tercera Relación de Chimalpahin y los Anales Mexicanos de México-Azcapotzalco, describen esta ofensa como la última que hizo Maxtla a los tenochcas como señor de Azcapotzalco y que preludió la guerra. Mientras que otros, como la Historia de Durán, la Crónica Mexicana, el Manuscrito Tovar, Códice Ramírez, y la Séptima Relación de Chimalpahin, describen el agravio como una acción no relacionada con la guerra contra Azcapotzalco, sino como uno de los motivos que llevaron al enfrentamiento con Coyoacan. 
Figura 6: Unidad TEMÁTICA 3, LÁMINA 11, en DURÁN, Historia DE LAS INDIAS DE NUEVA ESPAÑa E ISLAS DE LA TIERRa FIRME, MÉXICO, CA. 1579

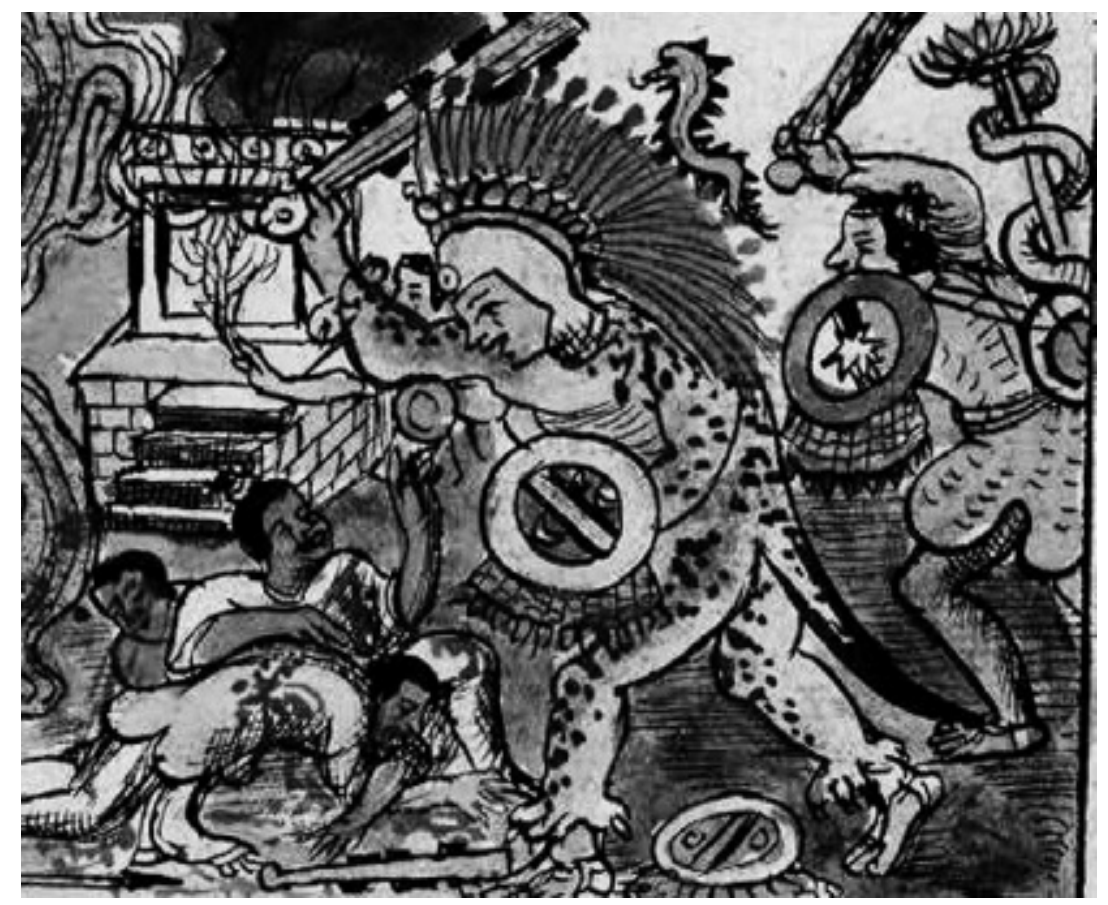

Foto: Fondo Reservado, Sala Cervantes, Núm. Vitr/ 26/11, Biblioteca Nacional de España, Madrid, f. 98 r.

mismo era una persona importante. El grupo de guerreros ostenta una actitud ofensiva.

En cuanto a las unidades temáticas 3 y 4 se encuentran separadas de la 1 y 2 por un río. En nuestra opinión esta vía acuática podría aludir a la línea fronteriza del foso de Mazatzintamalco, entre Petlacalco y Nonohualco, o tal vez a la ribera del lago a la altura de Nonohualco, por donde cruzan las huestes mexicas ${ }^{37}$. Como fuese, este elemento escinde la lucha en el campo de batalla en un primer momento, del posterior enfrentamiento en la ciudad.

Fuera de discusión, la tercera unidad temática se ostenta como la más importante del relato iconográfico, en principio porque la dimensión de sus

37 Chapman, 1959: 53. 
Figura 7: UNidAd TEMática 4, LÁMINA 11, eN DURÁN, HiSTORIA DE LAS INDIAS DE NUEVA ESPAÑa E ISLAS DE LA TIERRa FIRME, MÉXICO, CA. 1579

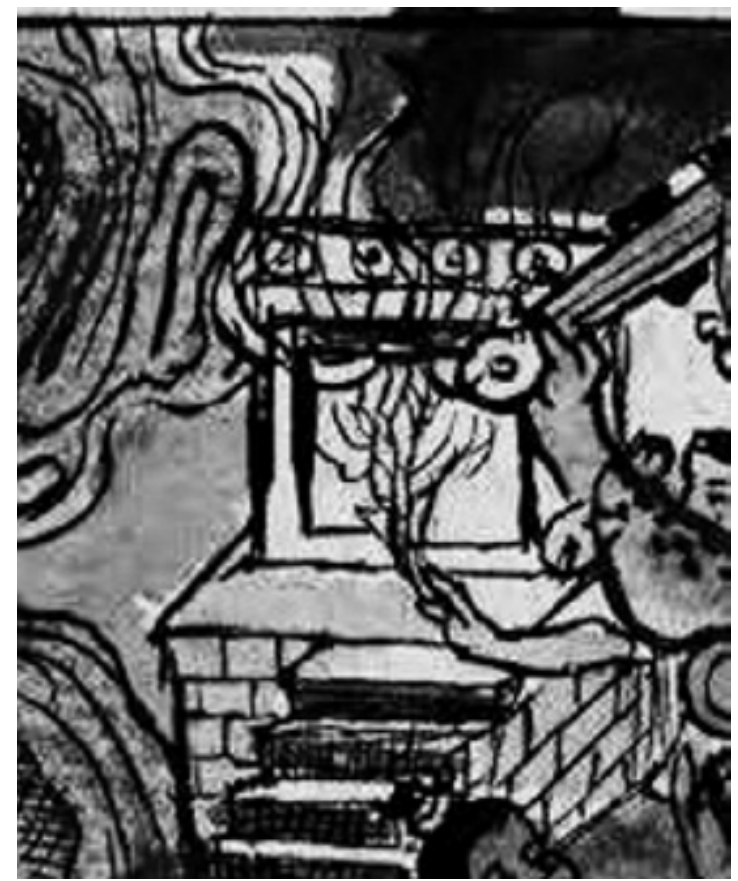

Foto: Fondo Reservado, Sala Cervantes, Núm. Vitr/26/11, Biblioteca Nacional de España, Madrid, f. 98 r.

figuras es notablemente mayor. La acción se desarrolla ya en el seno de la ciudad, frente a un edificio, y se perciben en ella cinco elementos. En primer lugar, aparece un señor ataviado con un tlahuiztli, traje de una sola pieza que cubría brazos y piernas, decorado con manchas de jaguar; en su cabeza hay un tocado de plumas de quetzal con dos bandas, lo que destaca su rango social. Además, tiene su glifo antropónimo: una serpiente con navajas, que nos permite identificarlo como Itzcoatl, tlahtoani de Tenochtitlan. El brazo izquierdo de Itzcoatl va protegido por chimalli, en tanto que con el derecho empuña un macahuitl. Justo frente a él yacen tres personajes, ensangrentados y desarmados, que han caído en la batalla. Sus armas, una flecha, un macahuitl y un chimalli, están a los pies de Itzcoatl. Uno de ellos, herido, agita ostensiblemente las manos, mientras que los otros que están a su lado han muerto. A la vera de Itzcoatl hay un guerrero, en actitud beligerante, con un estandarte en 
la espalda y un macahuitl, que esgrime amenazadoramente contra los guerreros vencidos.

La cuarta y última escena la conforman el templo quemado y un guerrero que porta en su mano una antorcha, lo que alude a la acción de incendiar o prender fuego. Según indica Alfredo López Austin, la imagen del templo quemado constituye una de las prácticas militares habituales de las culturas mesoamericanas. Un templo era considerado la casa del dios tutor, en donde se concentraba parte de su fuerza y de la de su pueblo, así pues, el que un enemigo lo hollara, destruyera la imagen y quemara el recinto significaba el término de toda la protección que el dios brindaba a su pueblo, lo que motivaba la rendición inmediata al invasor, sin ofrecer más resistencia ${ }^{38}$.

En suma: si bien la imagen bélica representada en la lámina 11 de la Historia de Durán puede haberse basado en un esquema convencional básico o genérico de representación de guerras en los códices indígenas, consideramos que los elementos que hemos aportado, y muy particularmente la presencia del topónimo Xoconochnopaltitlan, apuntaría a su identificación con la guerra de Azcapotzalco y no con la de Coyoacan o ninguna otra.

\section{Dos Representaciones bélicas de la SEGUNDa RELACIÓN De Tovar}

Por lo que toca a Juan de Tovar, la hipotética representación gráfica del enfrentamiento entre tenochcas y tepanecas se plasmó en sendas láminas a las que corresponde el numeral 9, tanto en el Manuscrito Tovar (véase figura 8) como en el Códice Ramírez (figura 9). Pero sólo en la numeración empieza y termina su coincidencia, pues las respectivas imágenes son totalmente diferentes.

Al observarlas lado a lado y compararlas, inevitablemente surgen interrogantes: ¿cuál fue la idea o el apoyo que tuvo Tovar para representar esta guerra? ¿por qué hay tantas diferencias entre ambas láminas? Desde luego, no es posible responder con certeza a estas preguntas, pero nuestra hipótesis es que, al leer la Historia de Durán, el jesuita posiblemente debió haber considerado que faltaba una pintura que representara la guerra fundamental que marcó el destino del pueblo mexica (ya antes hicimos referencia a su suposición de que la lámina 11 era alusiva al enfrentamiento con Coyoacan). Así pues, para subsanar la omisión, mandó copiar una ilustración que representara una acción bélica $y$, en este sentido, bien puede haberse desentendido de que la batalla plasmada no fuera ésa en particular, sino que se conformaría

38 López Austin, 1998: 59. 
Figura 8: Plancha III, "Figura 9. a De la Guerra de AzCapotzalco", TOVAR, Historia DE LA BENIDA DE LOS YNDIOS A POBLAR A MEXICO, MÉXICO, CA. 1585

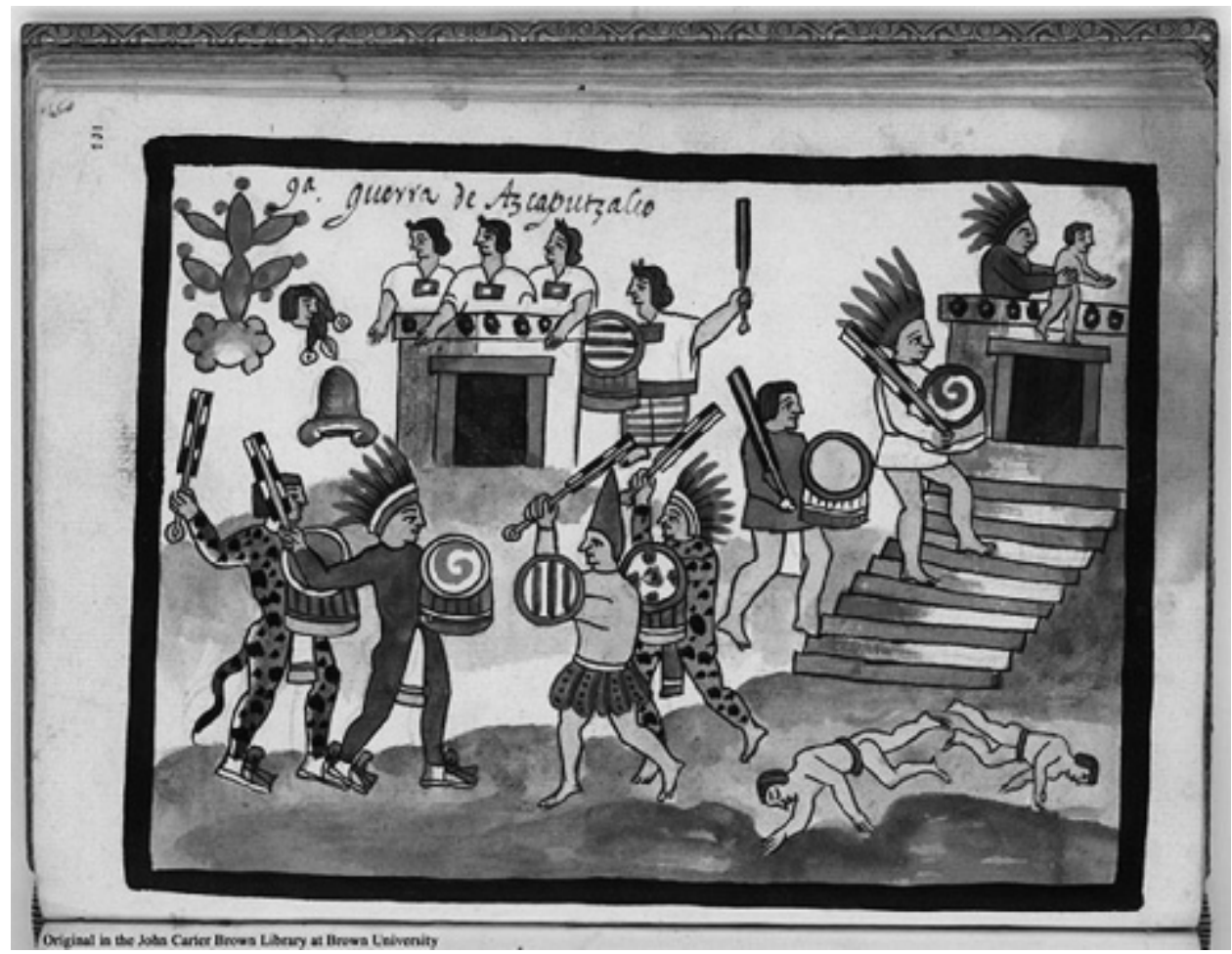

Foto: Collection Archive of early American Images, Codex Ind. 2, John Carter Brown Library, Brown University Providence, Rhode Island, f. 103.

una imagen genérica cualquiera, toda vez que tanto él como sus compañeros religiosos comprenderían perfectamente el contenido alusivo a la guerra. Tal suposición se apuntala en un significativo pasaje de una carta que Tovar dirigió a Joseph de Acosta:

El virey Don Martín Enriquez, teniendo deseo de saber estas antigüallas de esta gente con certidumbre, mandó juntar las librerías que ellos tenían de estas cosas y los de México, Tezcuco y Tulla se las traxeron [...] Embióme el Virey estos papeles y libros con el Doctor Portillo, provisor que fue de este Arzobispado, encargándome las viesse y averiguase, haciendo alguna relación para enviar al Rey. Ví entonces toda esta historia con caracteres y hyeroglificas que yo no entendía, y assí fue necessario que los sabios de México, Tezcuco y Tulla se viesen 
Figura 9: "LÁmina 9. La batalla que tuvo el rey AtLacaellel [Sic] CON LOS DE AZCAPOTZALCO QUE los Mató CASI A TODOS Y LOS SAQUEÓ DE GRANDES RIQUEZAS QUE TENÍAN POR SER LA CORTE DE LOS TEPANECAS", Códice RAMÍreZ, MÉXICO, Siglo XVI

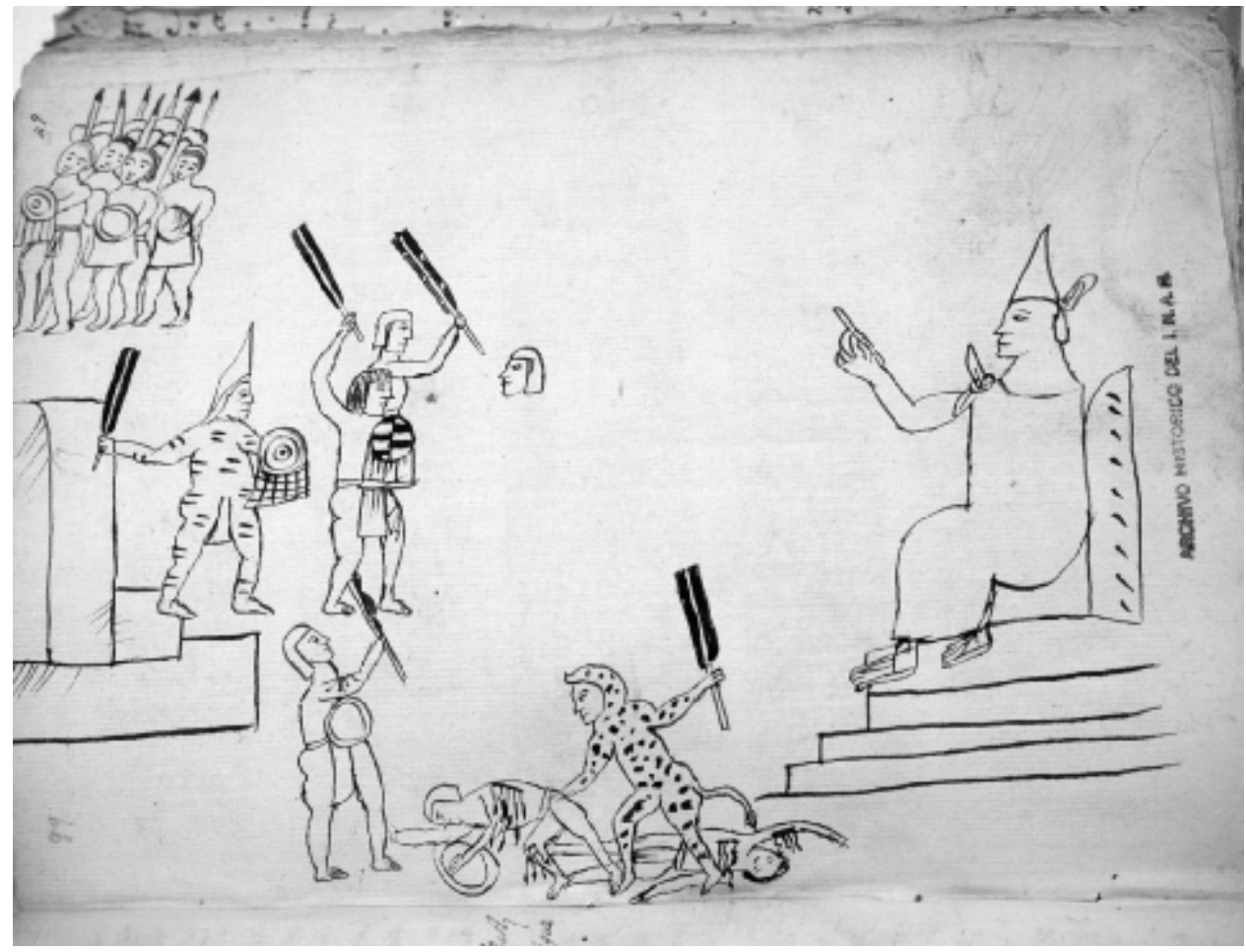

Foto: Códice Ramírez, Colección de Códices, núm. 166, Biblioteca Nacional de Antropología e Historia, México, f. 49 recto.

conmigo [...] y con ellos yéndome diziendo y narrando las cosas en particular, hize una Historia bien cumplida ${ }^{39}$.

Estas líneas demuestran que el jesuita reconocía abiertamente su incapacidad para la interpretación de códices pictográficos y, en consecuencia, su ignorancia respecto de los elementos plásticos específicos que empleaban los indígenas para la identificación de sucesos, personajes o lugares.

39 Tovar, 1972: 3-4. Las negritas son nuestras. 


\section{La lámina 9 del Manuscrito Tovar}

Esta plancha que ostenta la leyenda en caracteres latinos " 9. a de la Guerra de Azcapotzalco", consta de cuatro unidades temáticas que representan combates dentro de una ciudad. La descripción inicia en la parte superior izquierda de la foja, con tres glifos, de los que dos corresponden a topónimos: el de Tenochtitlan (el nopal naciendo de una piedra) y el de Tlatelolco (un montículo de arena), y en medio de ellos, está el tercero, que es antropónimo del señor Axayacatl de Tenochtitlan (quien inició su gobierno hacia 1473), conformado por una cabeza y agua. Abajo de los glifos, extendiéndose hacia el centro, aparecen cuatro guerreros: dos del lado izquierdo mirando hacia el lado derecho, que representan a los guerreros tenochcas, y dos de frente, que miran hacia la izquierda y que representan a los guerreros tlatelolcas, ya que son quienes tienen a sus espaldas la escena de su ciudad ${ }^{40}$.

En la parte superior central se ofrece a la vista lo que consideramos la segunda unidad temática: es un templo en la cima de un cerro; sobre su techo hay cuatro mujeres que - a diferencia de las que aparecen en la lámina de Durán - van vestidas de huipil blanco. Una de ellas se representa de cuerpo entero, de pie, al lado derecho del templo, con su huipil blanco decorado con una cenefa roja y con falda (cueitl) de rayas rojas y blancas. Empuña en la mano izquierda un macuahuitl y en la derecha un chimalli.

En la porción central derecha de la lámina, se observan dos personajes que ascienden por las escaleras del templo; el que va adelante porta un xicolli blanco, tocado de plumas de quetzal, chimalli y macuahuitl, mientras que el que va detrás viste xicolli azul, maxtlatl blanco, chimalli y macuahuitl. A la derecha, en los lados superior e inferior de la lámina se desarrollan escenas en la cumbre y en el pie de un templo. En la techumbre del templo se percibe a un señor vestido de ichcahuipilli azul y un tocado de plumas verdes, quien levanta por la cintura a un segundo personaje, desnudo y es de menor tamaño. Al pie de la escalinata hay dos figuras yacentes, vestidas sólo con maxtlatl azul. Es posible que esta escena represente el episodio en que Axayacatl arroja desde lo alto del templo al capitán tlatelolca, después de haber eliminado a los guerreros que lo acompañaban.

40 Los guerreros tenochcas portan trajes militares completos, uno de guerrero ocelote y el otro de guerrero cuextecatl de color rojo, este último no lleva el gorro yopi, sino que trae un tocado de plumas de quetzal con dos bandas, una roja y una blanca. Ambos personajes usan sandalias y llevan en sus manos chimalli y macuahuitl. El ataviado con el traje rojo podría ser Axayacatl, ya que va a la cabeza de las huestes tenochcas y se encuentra en primer plano. 
Luego de examinar minuciosamente la lámina 9 del Manuscrito Tovar y de haber llegado a la conclusión de que se trata de una representación de la guerra de Tlatelolco, se impone la necesidad de compararla con la representación de esta misma acción bélica que presenta la Historia de Durán y que corresponde a la pintura 22 .

Figura 10: "Guerra Contra Tlatelolco", Durán, Historia DE LAS INDIAS DE NUEVA ESPAÑa E ISLAS DE LA TIERRA FIRME, MÉXICO, CA. 1579

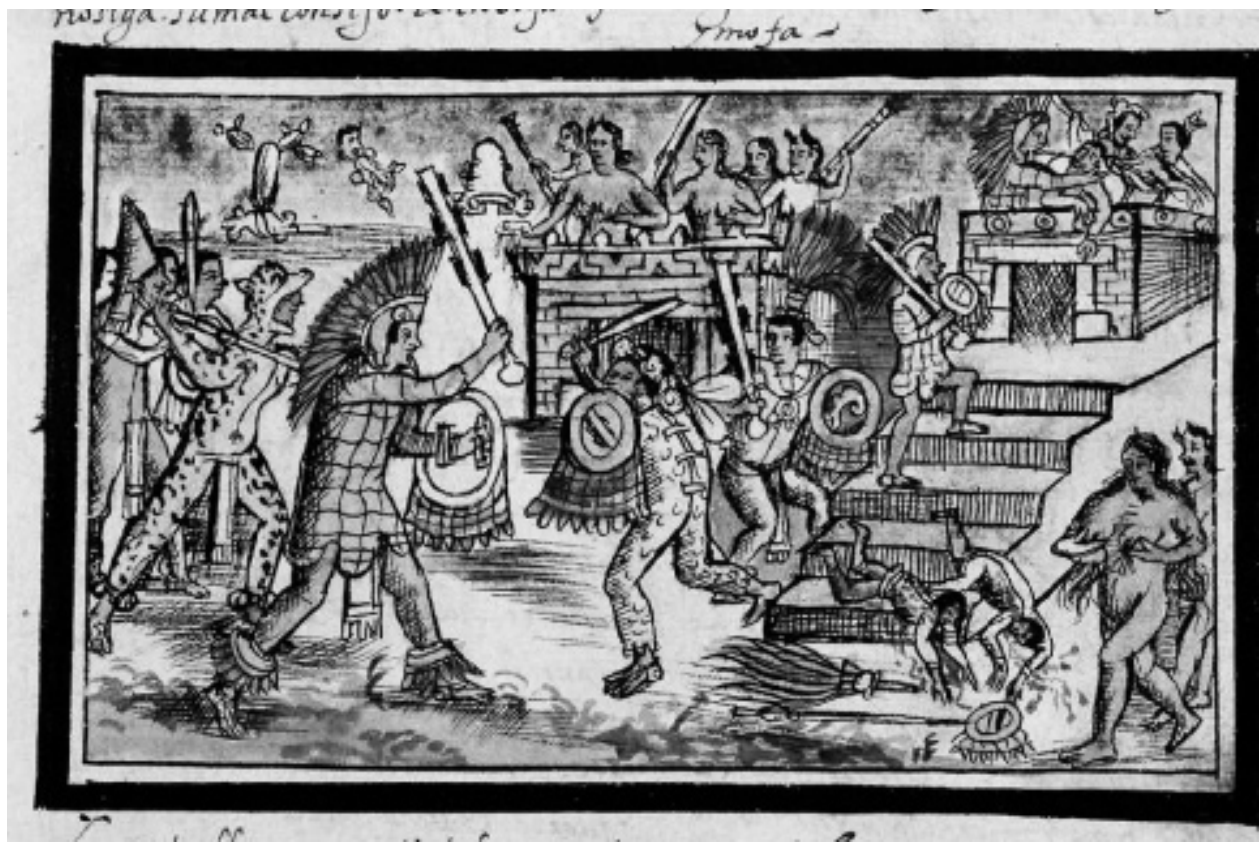

Foto: Fondo Reservado, Sala Cervantes, Núm. Vitr/ 26/11, Biblioteca Nacional de España, Madrid, f. 98 r.

Al igual que la lámina 9 del Manuscrito Tovar, la 22 de la Historia de Durán presenta cuatro unidades temáticas alusivas a hechos de armas en un escenario urbano. De manera similar, la composición se inicia en la parte superior izquierda de la foja, con los tres consabidos glifos: los dos topónimos que corresponden respectivamente a Tenochtitlan (el nopal que brota de la piedra) y Tlatelolco (un cerro) y en medio de ambos el antropónimo del señor Axayacatl, con el agua y la cabeza. 
En la parte central izquierda, se observan seis guerreros que miran hacia la derecha, hacia donde empuñan sus armas (chimalli, flechas y macuahuitl); dos de estos guerreros llevan atavíos de guerrero ocelote y guerrero cuextecatl o de Xipe Totec, ya que portan el gorro de yopi. Encabezándolos hay un guerrero de ichcahuipilli amarillo, que le cubre los brazos y las piernas hasta los muslos. Entre las piernas sobresale un maxtlatl blanco; lleva además un tocado de plumas verdes, de quetzal, sostenidas con una banda de color amarillo. Va calzado de sandalias y sus tobillos ostentan plumas verdes; empuña en su mano izquierda un chimalli y en la derecha esgrime un macuahuitl. Sobre él figura un antropónimo: una cabeza de cuya boca sale agua, «cara de agua o cara mojada», Axayacatl. Frente al tlahtoani tenochca, en actitud combativa, aparece un guerrero que mira hacia la izquierda, porta un traje de guerrero ocelote, sandalias, un tocado de plumas de quetzal y tres plumones en la frente en forma de borlas; en las manos carga su escudo y su macuahuitl. En la parte superior izquierda se percibe el glifo topónimo de Tlatelolco, que es la imagen de un cerro.

La segunda escena se extiende en la parte superior central y está constituida por la representación de un templo en forma de casa. Sobre el techo del «templo» hay cinco mujeres desnudas que, con sus manos izquierdas, oprimen uno de sus pechos y con las manos derechas empuñan palos.

La tercera unidad temática ocupa la porción central, pero cargada a la derecha, su acción se produce en el costado derecho de la escalinata del templo, en donde se muestra a un guerrero tlatelolca, cuya mirada se dirige a la izquierda y cuyo cuerpo, con las piernas flexionadas, se orienta a la derecha, como en actitud de iniciar la carrera. Justo al lado de dicha figura, por la escalinata, asciende Axayacatl hacia el templo. Esta tercera imagen plasma el momento en que Moquihuix emprende la retirada, trata de resguardarse en lo alto del templo y envía a sus guerreros y a un grupo de mujeres desnudas a detener el avance de Axayacatl.

La cuarta unidad temática también se ubica en el lado derecho y corre de la parte superior a la inferior de la lámina. En ella, sobre el techo del templo, Axayacatl echa mano a dos guerreros, uno de los cuales porta un penacho (y es el que nosotros identificamos como Moquihuix en la primera escena). A ambos los despeña del edificio y les ocasiona la muerte. Las armas, el tocado del guerrero y una flecha se esparcen por el suelo. Junto a sus cadáveres sangrientos se desplazan dos mujeres desnudas que se aprietan los senos.

Como se advierte, la estructura y la narrativa pictórica de la lámina 22 de la Historia de Durán y las de la 9 del Manuscrito Tovar son muy semejantes. Es muy alta la probabilidad de que el jesuita haya hecho copiar la representación de la guerra de Tlatelolco de la obra del dominico; no obstante, el 
tlacuilo encargado de ello introdujo variantes y cambios, entre los más notables: la disminución del número de personajes representados; la supresión de las imágenes de las mujeres desnudas que se oprimen los senos y su reemplazo por féminas vestidas de huipil y falda, sin omitir en este caso los palos o armas que, al igual que los guerreros, llevan en las manos y, finalmente, la representación de los guerreros muertos al pie de la escalinata, que en la lámina de Durán aluden a personajes de mayor dignidad y en la de Tovar a cautivos o combatientes comunes, cubiertos sólo con maxtlatl.

\section{La lámina 9 del Códice Ramírez}

Según su pie de imagen, la lámina 9 del Códice Ramírez dice representar específicamente la guerra tenochca contra Azcapotzalco. Sea de ello lo que fuese, sus cuatro unidades temáticas refieren el desarrollo de un combate en un escenario citadino.

De izquierda a derecha, la primera escena en el ángulo superior describe a un grupo de guerreros alineados y armados con chimalli y lanzas, que, sin embargo, marchan hacia el lado contrario de donde se desarrolla la batalla, como en retirada. La segunda unidad temática figura en el centro de la lámina y baja por el mismo lado izquierdo; consta de cinco elementos: un edificio, del que parece salir un guerrero enfundado en un traje de yopi, que lleva un chimalli, decorado con círculos que recuerdan una espiral, y un macahuitl. Frente a él, otros dos guerreros vestidos con maxtlatl y protegidos con chimalli empuñan amenazadoramente su macahuitl. Frente a ellos está lo que parece ser la figura de otro guerrero que aparenta confrontarlos, pero de esta imagen sólo se ve la cabeza, lo que lleva a pensar - y también por la falta de detalles en el paisaje - que, por alguna razón, la lámina quedó inconclusa.

La figura prominente en la tercera unidad, a la vista de su tamaño, es la de un señor que, vestido de tilmatli y xihuitzolli, mira el combate sentado en su estera con respaldo. Ésta se asienta en la parte alta de un edificio dotado de escalinata. El brazo derecho del personaje señala hacia el campo de batalla.

Al pie de la escalinata antes mencionada está la escena de la cuarta unidad. En ella hay dos guerreros tendidos en el suelo, tal vez heridos, tal vez muertos; un tercero que viste un traje completo de guerrero jaguar alza su $m a$ cuahuitl como en actitud de rematar a uno de los caídos. Frente a éste, hay otro combatiente, vestido con maxtlatl y herido en el brazo diestro que, no obstante, levanta desafiante su arma hacia el señor que observa la acción desde lo alto. 
A diferencia de su homóloga reproducida en el Manuscrito Tovar, esta lámina carece de glifos topónimos y antropónimos que nos ayuden a identificar de qué guerra o lugar se trata y, en este sentido, podría tomarse sólo como una ilustración bélica general. Empero, las características de su factura, sus trazos elementales y su carencia de policromía nos inducen a pensar que, al igual que el resto de las pinturas que integran el Códice Ramírez, bien pudo haber sido obra de la misma mano que escribió el texto en caracteres latinos. Porque cabe indicar que, a diferencia del Manuscrito Tovar, las láminas del Códice Ramírez van acompañadas de notas explicativas sobre su contenido. Como se ha dicho antes, ésta tiene la siguiente indicación: «Lámina 9. La batalla que tuvo el rey Atlacaellel [sic] con los de Azcapotzalco que los mató casi a todos y los saqueó de grandes riquezas que tenían por ser la corte de los Tepanecas ${ }^{41}$. Como puede advertirse, el texto da por sentado —erróneamente- que «el rey» Tlacaelel era el tlahtoani de Tenochtitlan, cuando lo cierto es que quien gobernaba era Itzcoatl.

$\mathrm{Al}$ igual que procedimos con la lámina 9 del Manuscrito Tovar, nos dimos luego a la tarea de buscar una ilustración en la Historia de Durán que representara una guerra y cuyos rasgos de composición fuesen semejantes a los de la lámina 9 del Códice Ramírez. De este modo encontramos la pintura 12, en la foja 37 r. de la obra del dominico, relativa a la guerra contra Xochimilco y que guarda bastantes similitudes con la referida del Códice Ramírez.

Empecemos el análisis de la lámina 12 de Durán, donde se contabilizan cuatro unidades temáticas, no sin antes señalar que el tlacuilo combinó muy hábilmente el paisaje con los elementos indígenas, lo que brinda gran movilidad y profundidad al espacio plástico. La primera escena abarca la parte inferior y media del extremo izquierdo y parte del área central. Presenta un edificio y un patio o jardín florido donde el aparece un señor ataviado con iztac xomoihuitilmatlit ${ }^{42}$, (tilma cuyos bordes van decorados de ojitos), un maxtlatl blanco y un tocado de plumas verdes. Le acompañan dos hombres que, al igual que su señor, miran a lo alto de un cerro cuyo pie está rodeado de flores. En la cumbre hay un par de guerreros con ixcahuipilli; ambos portan chimalli, sólo que el de la derecha alza en ristre una flecha, y el de la izquierda un macahuitl. El cerro y el patio floridos podrían aludir o ser representación del topónimo de Xochimilco, «en el lugar de la sementera de flores». Atrás de esta escena, en el ángulo superior izquierdo y en segundo plano

41 Códice Ramírez, Versión microfilm de la Biblioteca Nacional de Antropología e Historia, Serie Misceláneas, rollo 51: 98.

42 Olko, 2005: 194. 
Figura 11: "La GUerra CONTRA Xochimilco", Durán, Historia DE LAS INDIAS DE NUEVA ESPAÑa E ISLAS DE LA TIERRa FIRME, MÉXICO, CA. 1579

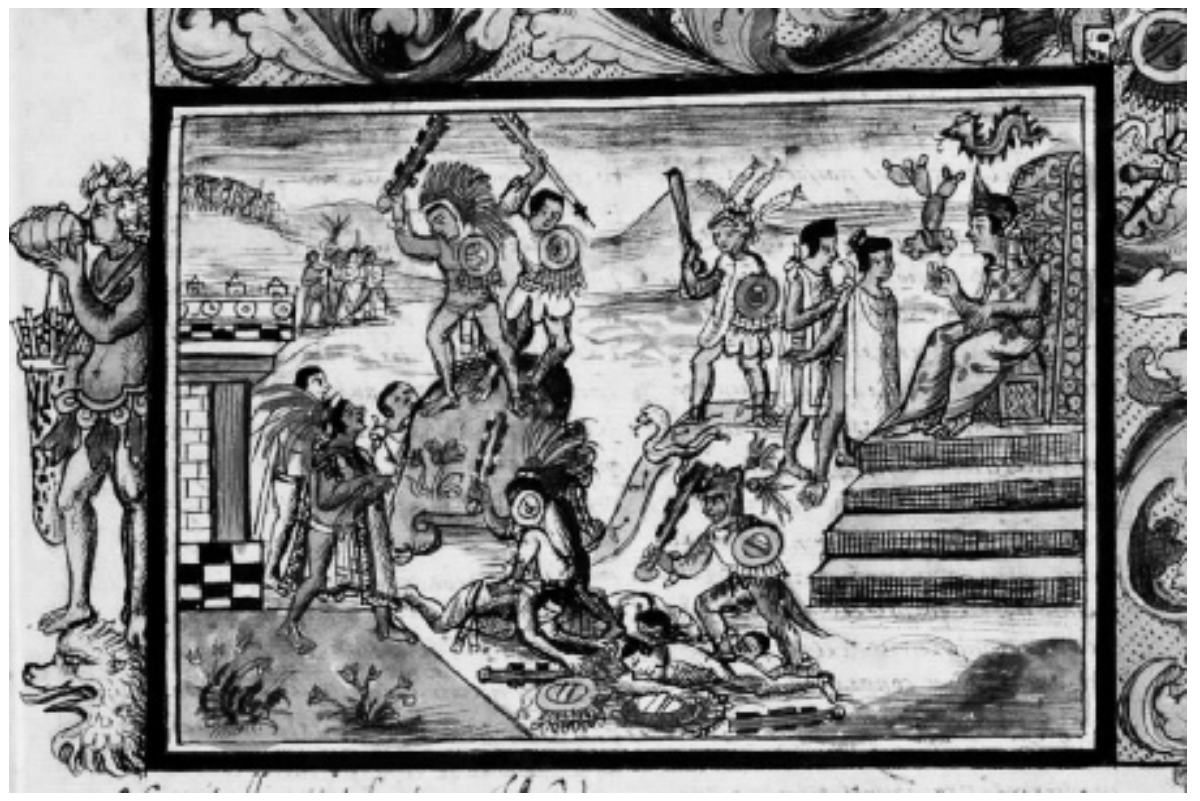

Foto: Fondo Reservado, Sala Cervantes, Núm. Vitr/ 26/11, Biblioteca Nacional de España, Madrid, f. 98 r.

— para lo que el tlacuillo se sirvió de la perspectiva — se distinguen dos grupos de guerreros que parecen aproximarse.

La segunda unidad ocupa el lado derecho de la pintura; el personaje principal es un señor sentado en una estera en forma de trono que se encuentra en lo alto de un edificio con escalinatas. Va ataviado con tilmatli decorada con flores rojas y un xihuitzolli. A la altura de su rostro se advierte el glifo topónimo de Tenochtitlan y sobre su cabeza su glifo antropónimo: una serpiente con navajas, que inequívocamente lo identifica como Itzcoatl, tlahtoani de Tenochtitlan. Frente a Itzcoatl, pero al pie del edificio, hay dos varones que parecen dialogar con él; su atuendo son tilmas blancas, maxtlatl y sandalias.

La tercera unidad temática comienza precisamente en la parte media superior de la lámina, detrás de los señores que hablan con Itzcoatl. Aquí se ofrece a la vista un guerrero vestido con ixcahuipilli y un tocado de plumas en la cabeza, lleva en sus manos chimalli y macahuitl y se le representa sobre un camino con huellas que lo dirige al campo de batalla. 
En la parte central inferior de la lámina se ubica la cuarta unidad temática que consta de seis figuras humanas. A la izquierda de la escena hay un guerrero vestido de ixcahuipilli y tocado de plumas, a la derecha está otro en traje de guerrero jaguar; sobre la cabeza de éste figura un glifo antropónimo, una serpiente, que si bien podría aludir a Itzcoatl, carece del cuerpo de obsidianas que es distintivo. Ambos combatientes se empeñan en masacrar con sus macahuitl a los cuatro enemigos, que, cubiertos sólo con maxtlatl, yacen a sus pies, y cuyos chimalli y macahuitl están esparcidos por el suelo y ensangrentados.

Evidentemente, la lámina 9 del Códice Ramírez comparte en buena medida la organización temática con la 12 de Durán, aunque esta última incluye muchos más elementos narrativos, lo que permite identificar a los protagonistas y ubicar espacial y temporalmente la acción de armas, en mucho por el movimiento y la variedad de escenarios. Descontando las obvias diferencias en la calidad de los respectivos artífices, puede presumirse que la de Durán sirvió como base o inspiración para la de Tovar, aunque en ésta se hayan omitido multitud de detalles, tal vez deliberadamente, bien por las escasas habilidades pictóricas de quien la elaboró o bien para suprimir los indicadores de lugar y época. En este sentido, también es posible afirmar que la lámina 9 del Ramírez simplemente sirvió para ilustrar genéricamente el texto relativo a la guerra de Azcapotzalco.

\section{CONSIDERACIONES FINALES}

Luego del prolijo examen comparativo presentado sobre los textos y las diversas ilustraciones de la Historia de Durán y de la Segunda Relación de Tovar, hemos llegado a las siguientes conclusiones:

La lámina 11 de Durán no representa la guerra contra Coyoacan, como secularmente se ha creído, sino contra Azcapotzalco, según la evidencia del encuentro de tenochcas y tepanecas en Xoconochnopaltitlan, justo en la ribera del lago, y la del momento climático que representó la caída de Azcapotzalco en manos de Itzcoatl. Los problemas para su identificación, como ya se ha expuesto, radicaron en la ausencia de glifos topónimos y antropónimos (cosa insólita, pues las demás láminas de Durán los incluyen) y en la colocación de la ilustración, al final del texto relativo a esa guerra y al principio del relato de la de Coyoacan.

La lámina 9 del Manuscrito Tovar no ilustra la guerra mexica contra Azcapotzalco, sino la que los tenochcas le hicieron a Tlatelolco. En su aprovechamiento de los materiales de Diego Durán, el jesuita Tovar - ya por desconocimiento, ya por simplificación - posiblemente decidió tomar algunas 
láminas y hacerlas copiar para cubrir lo que consideró vacíos pictóricos importantes. De este modo muy probablemente echó mano de la pintura 22 de Durán, relativa a la guerra entre tlatelolcas y tenochcas, para emplearla como modelo de la guerra entre mexicas y tepanecas de Azcapotzalco, destinando la plancha 10 que comparte composición con la lámina 11 de la Historia de Durán, a ilustrar la batalla contra Coyoacan, bajo el título "9. a Guerra contra Coyuacan", teniendo la obra dos láminas con la misma signatura.

Finalmente, la lámina 9 del Códice Ramírez, también de Tovar, que hipotéticamente se refiere igualmente a la guerra contra Azcapotzalco, se debió inspirar en la 12 de Durán, que es representativa de la campaña de los mexicas contra Xochimilco.

De todo esto también se concluye que Durán, sus tlacuilos y auxiliares debieron trabajar en estrecha colaboración, intercalando las imágenes en el texto y cerciorándose de que las pinturas se integraran en el sitio correcto y en perfecta coincidencia con el relato alfabético en cuanto a escenas, lugares y personajes. A diferencia del cronista jesuita, quien, al parecer, para el $\mathrm{Ma}$ nuscrito Tovar encargó la elaboración de sus pinturas a tlacuilos, sin supervisarlas personalmente, y luego las integró al final de su obra, asignándoles títulos. Mientras que en el caso del Códice Ramírez muy posiblemente la misma mano del texto alfabético se encargó de la elaboración de los dibujos, aunque de manera separada. Posteriormente, se intercalarían estas ilustraciones, junto con sus encabezados.

Sin embargo, aún gravitan algunas preguntas que de momento no parecen encontrar solución ¿por qué, a pesar de haber sido posteriores a las de la Historia de Durán, las láminas de Tovar presentan elementos iconográficos que parecen anteriores? ¿Tuvo el padre Tovar en sus manos el ejemplar que conocemos como Historia de Durán o es posible que haya existido otro ejemplar, distinto, de ella? Si Juan de Tovar no se sirvió de los modelos de la obra de fray Diego para realizar sus láminas, ¿a qué fuente, semejante en su composición a la obra de Durán, pudo haber recurrido? ¿Por qué razón las láminas del Códice Ramírez parecen inconclusas?

Reconocemos que nuestro trabajo hace una aproximación muy puntual, casi diríamos microscópica, de ciertos aspectos de los extensos y complejos textos de Durán y Tovar, que están emparentados. Pero igualmente consideramos que este análisis es un primer paso para desentrañar las formas de elaboración de dichas obras y su material pictográfico, porque como hemos apuntado en otro lugar, son escasísimos los estudios sobre esta temática.

Naturalmente, no consideramos que nuestra aproximación al contenido pictórico de las obras de Durán y Tovar sea la definitiva ni la única forma de abordarlo. Muy por el contrario, creemos indispensable el concurso de espe- 
cialistas en diversas disciplinas en futuros análisis de dichos materiales, si es que aspiramos a que sus textos e ilustraciones nos revelen algún día lo que sus autores realmente quisieron contarnos.

\section{BIBLIOGRAFÍA}

Alva Ixtlilxochitl, Fernando de, Sumaria Relación de las cosas de Nueva España, Obras históricas, 2 vols., edición, estudio introductorio y apéndice documental de Edmundo O'Gorman, México, Universidad Nacional Autónoma de México, Instituto de Investigaciones Históricas, 1975. Serie de Historiadores y Cronistas de Indias, 4.

Alvarado Tezozómoc, Fernando, Crónica Mexicana. Precedida del Códice Ramírez manuscrito del siglo XVI intitulado: Relación del origen de los Indios que habitan en esta Nueva España según sus historias, 4. ${ }^{\text {a }}$ ed., Anotaciones y Estudio Cronológico de Manuel Orozco y Berra, México, Porrúa, 1987.

Anales de Tlatelolco, Paleografía y Traducción de Rafael Tena, México, CONACULTA, 2004.

Barlow, Robert H., "La crónica X, versiones coloniales de la historia de los mexica-tenochca", Robert Barlow, Los mexicas y la Triple Alianza, editado por Jesús Monjarás-Ruiz, Elena Limón y María de la Cruz, Puebla, Instituto Nacional de Antropología e Historia/Universidad de las Américas, 1990: 13-32. Obras de Robert H. Barlow, 3 .

Bautista, Juan, ¿Cómo te confundes? ¿A caso no somos conquistados? Anales de Juan Bautista, Edición y traducción del náhuatl al español por Luis Reyes García, México, Centro de Investigaciones y Estudios Superiores en Antropología Social, Biblioteca Lorenzo Boturini, Insigne y Nacional Basílica de Guadalupe, 2001.

Bernardino de Sahagún, "Libro de la Conquista de México", Carlos María de Bustamante, La aparición de Ntra. Señora de Guadalupe de México, comprobada con la refutación del argumento negativo que presenta D. Juan Bautista Muñoz, fundándose en el testimonio del P. Fr. Bernardino de Sahagún, México, Ignacio Cumplido, 1840: XXII y 247.

Camelo, Rosa de Lourdes y Romero Galván, José Rubén, "Estudio Preliminar", Diego Durán, Historia de las Indias de Nueva España e Islas de la tierra firme, 2 vols., México, CONACULTA, 2002. Cien de México.

Carrasco, Pedro, The Tenochca Empire of Ancient Mexico: The Triple Alliance of Tenochtitlan, Tetzcoco and Tlacopan, Oklahoma, University of Oklahoma Press, 1999.

Chapman, Anne, Raíces y consecuencias de la guerra de los aztecas contra los tepanecas de Azcapotzalco, Acta Anthropológica, México, Escuela Nacional de Antropología e Historia, Sociedad de Alumnos, 1959. Época 2, I/4: 11-123. 
Chimalpahin Cuauhtlehuanitzin, Domingo Francisco de San Antón Muñón, Diario de Don Domingo de San Antón Muñón Chimalpáhin, 1579-1660, Biblioteca Nacional de Francia, París, Departament des Manuscrits, Mexicain 220, Manuscrito, 284 folios.

Chimalpahin Cuauhtlehuanitzin, Domingo Francisco de San Antón Muñón, "Diario de Don Domingo de San Antón Muñón Chimalpáhin, 1579-1660”, Gallica, Bibliotéque Numérique de la Biblioteca Nacional de Francia, París, 300 imágenes, http://gallica.bnf.fr/ark:/12148/btv1b8562411r.r =diario + de + domingo + de + san + anton.langes.

Chimalpain Cuauhtlehuanitzin, Domingo Francisco de San Antón Muñón, Primer amoxtli libro. Tercera relación de la différentes Histoires Originales, Estudio, paleografía, traducción, notas repertorio y apéndice de Víctor Manuel Castillo Farreras, México, Universidad Nacional Autónoma a de México, Instituto de Investigaciones Históricas, 1997.

Chimalpahin Cuauhtlehuanitzin, Domingo Francisco de San Antón Muñón, Diario, paleografía y traducción de Rafael Tena, México, CONACULTA, 2001. Cien de México.

Chimalpain Cuauhtlehuanitzin, Domingo Francisco de San Antón Muñón, Annals of his time, edited and translated by James Lockhart, Susan Schoeder and Doris Namala, Stanford, Stanford University Press, 2006.

Códice Ramírez. Manuscrito del siglo XVI, intitulado: Relación del Origen de los indios que habitan en esta Nueva España según sus historias, versión microfilm de la Biblioteca del Museo Nacional de Antropología e Historia (México), Serie Misceláneas, rollo 51 .

Códice Ramírez, Manuscrito del siglo XVI, intitulado: Relación del origen de los indios que habitan en esta Nueva España según sus historias, examen de la obra y cronología mexicana de Manuel Orozco y Berra, México, Innovación, 1979.

Códice Xólotl, edición, estudio y apéndice de Charles E. Dibble, 2. ${ }^{\mathrm{a}}$ ed., 2 vols., México, Universidad Nacional Autónoma de México, Instituto de Investigaciones Históricas, 1980. Serie Amoxtli, 1.

Dávila Montoya, Alejandra, La Conquista de México en la Relación del origen de los indios que habitan en esta Nueva España según sus historias, del padre Juan de Tovar, tesis de licenciatura en Historia, México, D.F., UNAM, 2005.

Durán, Diego, Historia de las Indias de Nueva España e Islas de la tierra firme, 1579, versión digital del original de la Biblioteca Nacional de Madrid, http://bdhrd.bne.es/viewer.vm?id=0000169486\&.

Durán, Diego, Historia de las Indias de Nueva España e Islas de la tierra firme, estudio preliminar de Rosa Camelo y José Rubén Romero Galván, 2 vols., México, Cien de México, 2002. 
Galarza, Joaquín y Zamez, Abraham, La lectura de la "Imagen Azteca”. El retrato real en la escritura azteca. Cuadros del Códice Tovar, México, CIESAS, Editorial Aguirre Beltran, Escuela Nacional de Antropología e Historia, 1986, 110 pp.

García Icazbalceta, Joaquín, "Bibliografía Mexicana del siglo XVI”. Catálogo razonado de libros impresos en México de 1539 a 1600. Precedido de una noticia acerca de la instrucción de la imprenta en México, edición de Carlos Agustín Millares, México, Fondo de Cultura Económica, 1954.

Lafaye, Jacques, "El Manuscrito Tovar de la John Carter Brown Library: Atribuciones y Filiaciones”, Miscelánea de la Casa de Velázquez, VI, (París, 1970): 359371.

Launey, Michel, Introducción a la lengua y a la literatura náhuatl, traducción de Cristina Kraft, México, UNAM, Instituto de Investigaciones Antropológicas, 1992.

Leal, Luis, "El libro XII de Sahagún”, Historia Mexicana. Revista trimestral publicada por el Colegio de México, 5/2 (México, Octubre-Diciembre 1955): 184-210.

López Austin, Alfredo, Hombre-Dios. Religión y Politica en el mundo náhuatl, 3. a ed., México, UNAM, Instituto de Investigaciones Históricas, 1998.

Maynez Vidal, Pilar, Fray Diego Durán. Una interpretación de la Cosmovisión Mexicana, México, UNAM/Escuela Nacional de Estudios Profesionales Acatlán, 1997.

Molina, Alonso de, Vocabulario en Lengua Castellana y Mexicana, México, Editorial Porrúa, 2001.

Noguéz, Xavier, "Las ilustraciones en la obra de Diego Durán”, Arqueología Mexicana, 19/116 (México, 2012): 16-17.

O’Gorman, Edmundo, “Apéndice Tercero. Fr. Diego Durán, el P. Juan de Tovar y la Historia Natural y moral de las indias del P. José de Acosta (Textos y opiniones)", Joseph de Acosta, Historia Natural y moral de las Indias. En que se tratan de las cosas notables del cielo, elementos metales, plantas y animales dellas y los ritos y ceremonias leyes y gobierno de los indios, 2. ${ }^{\text {a }}$ ed., edición, prólogo, tres apéndices e índice de materiales de Edmundo O’Gorman, México, Fondo de Cultura Económica, 1962.

Olko, Justyna, Turquoise diadems and staffs of office. Elite Costume and insignia for power in Aztec and early Colonial México, Waszawa, Oâsrodek Badaân nad Tradycjna Polsce iw Europie asrodkowo-wschodneij, 2005.

Robertson, Donald, "Paste-over illustrations in the Duran Codex of Madrid", Tlalocan. Revista de Fuentes para el Conocimiento de las Culturas Indígenas de México, V/4 (México, 1968): 340-348.

Torquemada, Juan de, Monarquía indiana de los veinte y un libros rituales y monarquía indiana, con el origen y guerras de los indios occidentales, de sus poblazones, descubrimiento, conquista, conversión y otras cosas maravillosas de la 
mesma tierra firme, 3. ${ }^{a}$ ed., vol. 1, edición de Miguel León-Portilla y otros, México, Universidad Nacional Autónoma de México, Instituto de Investigaciones Históricas, 1986. Serie de Historiadores y Cronistas de Indias, 5, 1975-1983.

Tovar, Juan de, Manuscrit Tovar. Origine et croyances des indiens du Mexique, "Relación del origen de los indios que habitan en esta Nueva España según sus historias. Tratado de ritos y ceremonias y dioses que en su gentilidad usaban los indios de esta Nueva España”, edición de Jaques Lafaye, Graz, Austria, Akademische Diek, 1972.

Tovar, Juan de, Historia y creencias de los indios de México, edición, prólogo, notas y comentarios de José J. Fuente de Pilar, trascripción al castellano moderno de Susana Urraca Uribe, Madrid, Miraguano, 2001, 295 pp.

Tovar, Juan de, Historia de la benida de los yndios a poblar a Mexico, original de la John Carter Brown Library, Archive of Early American Imágenes, The John Carter Brown Library, Brown University, en línea, disponible en: http://jcb.lunaimaging.com/luna/servlet/view/search?QuickSearchA =QuickSearchA\&q=tovar+manuscript\&sort=IMAGE_DATE\%2Csubject_groups. 103.

Fecha de recepción: 18 de marzo de 2015.

Fecha de aceptación: 7 de julio de 2015.

\section{Illustrations of the Tenochca wars in Tovar and Durán. Versions and misunderstandings}

There are two versions of the war between Tenochtitlan and Azcapotzalco in three sources of indigenous tradition from the second half of the sixteenth century: Fray Diego Duran's History of the Indies of New Spain, and the two taken from Juan de Tovar's Segunda Relacion: the Codex Ramirez and the Tovar Manuscript. Through analysis of the differences between the alphabetic and the pictographic accounts of this episode in these sources, this paper presents and discusses the disparities and misinterpretations regarding the pictographic materials that accompany these works.

KeY WORDS: war; Azcapotzalco; Tenochtitlan; images; Duran; Tovar. 